\title{
MONUMENTALNA NADGROBNA ARHITEKTURA I RELJEFNA SKULPTURA RIMSKE ENONE (AENONA)
}

\author{
Martina DUBOLNIĆ GLAVAN \\ Zavod za povijesne znanosti HAZU u Zadru \\ Zadar, Hrvatska \\ Dražen MARŠIĆ \\ Sveučilište u Zadru, Odjel za arheologiju \\ Zadar, Hrvatska
}

\author{
UDK: $902 / 904: 726.82$ \\ DOI: https://dx.doi.org/10.21857/9e31lhnv4m \\ Izvorni znanstveni rad \\ Prihvaćeno: 26. travnja 2019.
}

Prihvaćanje rimskih kulturnih tekovina na prostoru Liburnije očituje se, među ostalim, i u funerarnoj praksi podizanja vrlo raskošnih i monumentalnih građevina kao vječnih počivališta pripadnika društvene elite i njihovih obitelji. Dokazi njihova postojanja rijetko su sačuvani, a zbog fragmentarnosti i anepigrafskog karaktera često su ostajali izvan fokusa znanstvenih istraživanja. U ovom se radu po prvi put integralno obrađuju temeljni ostatci, konstruktivni elementi i reljefi s portretima pokojnika nekoć uzidani u pročelja grobnih zdanja (tzv. ugradbeni reljefi), kao dokazi postojanja različitih tipova monumentalne nadgrobne arhitekture i skulpture na prostoru rimskog municipija Aenona (Nin). Posebno se analiziraju i interpretiraju ostatci mauzoleja istraženog davne 1972. g. u ruralnoj gradskoj okolici (položaj Kulina u Vrsima), koji su arheološkoj javnosti slabo poznati. U istom se kontekstu također obrađuju četiri ugradbena reljefa s prikazima pokojnika te skulpture sfingi. Posebna se pozornost posvećuje fragmentu trabeacije „hramske grobnice“ obitelji Lartius iz Nina, koji do sada nije bio prepoznat i valoriziran. Za studiju monumentalnih grobnih zdanja vrlo je važan i njihov funerarni kontekst. $U$ radu je stavljen naglasak i na podatke o veličini grobnih areala te tipologiju prisutnih nadgrobnih spomenika, a posebice su sumirani rezultati recentnih istraživanja rastera gradskih nekropola. Analogije za rekonstrukciju izgleda pojedinih građevina, te njihovu funkciju i smještaj u okviru gradskih nekropola, mogu se naći u Saloni i Jaderu, a češće na gradskim nekropolama Rima. Kao okosnica istraživanja provedenih za potrebe ovoga rada poslužila je muzejska građa i dokumentacija pohranjena u Arheološkom muzeju Zadar i Muzeju ninskih starina u Ninu. Rezultati tipološko-komparativne metode primijenjene u analizi spomenika nadopunjeni su i podatcima prikupljenim istraživanjima arhivske građe. Studija rastera gradskih nekropola uključila je i metode arheologije krajolika, pa su u raspravi također implementirani i rezultati arheološkog terenskog pregleda i daljinskih istraživanja provedenih u ninskoj gradskoj okolici.

Ključne riječi: Aenona, rimske nekropole, grobni areali, mauzoleji, ugradbeni reljefi, portreti.

\section{UVOD}

Uz Nadin, Aseriju i Varvariju, Enona (Aenona) je bez sumnje najznačajnije liburnsko i rimsko naselje Liburnije. Kontinuitet naseljenosti njezina urbanog središta - prostora današnjeg ninskog „otoka“ - najbolje posvjedočuju nalazi 
željeznodobnih, rimskih i srednjovjekovnih grobova, a tek u manjoj mjeri i ostatci arhitekture. Inventar otkriven u rimskim grobovima toliko je bogat i raznovrstan da je svojevremeno činio okosnicu postava zadarskog Muzeja u crkvi sv. Donata. No u isto su vrijeme podatci o kontekstu rimskodobnih nalaza najblaže rečeno oskudni. U literaturi se samo šturo spominje tijek i okvirni položaj poduzetih istraživanja, a do zaključnog izvješća i primjerene objave otkrivene arheološke građe najčešće nije ni došlo. ${ }^{1}$ Tako imamo situaciju da ne raspolažemo cjelovitim i objelodanjenim podatcima ni za jedan jedini rimski grob! Sadržaj nekoliko grobnih cjelina prezentiran je tek na rijetkim fotografijama u starijim radovima, dok je veća količina materijala iz ninskih nekropola poznata iz parcijalnih objava. ${ }^{2}$ Za poznavanje ninske građe značajni su radovi tematskog karaktera te katalozi i vodiči po Arheološkom muzeju u Zadru, ${ }^{3}$ pogotovo oni objavljeni prije Drugog svjetskog rata, u vremenu dok je zbirka prikupljene građe još bila cjelovita i s koliko-toliko urednim podatcima o okolnostima nalaza. Naime, tijekom

1 Usporedi Martina Dubolnić Glavan, Civitas Aenona, primjer romanizacije liburnske općine, Sv. I - II, Doktorski rad, Zadar, 2015., 90 - 95, Dodatak 1 - 3; Karta 1 - 2, br. 142-24, 144-26, 145-32.

2 Vidi u: Mihovil Glavinić, Römische Funde in Nin, Dalmatien, Mittheilungen der $k$. $k$. CentralCommission zur Erforschung und Erhaltung der Kunst-und Historischen Denkmale, n.f., 21, Wien - Leipzig, 1895.; Julius BAnkó, Piero Sticotтi, Antiken - Sammlung im Erzbischöfl. Seminare zu Udine, Sonder-absdruck aus Archaeologisch-epigraphische Mittheilungen aus Oesterreich-Ungarn, XVIII, Wien, 1895., kao i radovi objavljeni 1896.i 1897.g.; Luka JeLIĆ, Spomenici grada Nina, Vjesnik Hrvatskoga arheološkoga društva, god. V, Zagreb,1901., 185; Giuseppe BERSA, Iscrizioni inedite, Bullettino di archeologia e storia Dalmata, 23, Spalato, 1900.; Giuseppe BERSA, Le lucerne fittili romane di Nona conservate al Museo archaeologico di S. Donato di Zara, Bullettino di archeologia e storia Dalmata, 25, Spalato, 1902., kao i radovi o uljanicama objavljeni 1903., 1906., i 1915.; Giuseppe BERSA, Grabfunde aus Nona (Dalmatien), Mittheilungen der k. k. Zentralkommission für Erforschung und Erhaltung der Kunst- und hist. Denkmale, Bd. IV, 4-5, Wien, 1905.; Vitaliano BRUNeLLI, Storia della città di Zara, I, Venezia, 1913.; Arnolfo ВАсотісн, Appunti per la storia della città di Nona con speciale riguardo all'origine della sua Chiesa, Archivio storico per la Dalmazia, Vol. V, 25, Roma, 1928.; Usporedi Mate SuIć, Nin u antici, Nin - problemi arbeoloških istraživanja, Zadar, 1968., T. XXX - XXXI; Mate SuIć, Antički Nin (Aenona) i njegovi spomenici, Povijest grada Nina (ur. G. Novak, V. Maštrović), Zadar, 1969., Sl. 18 - 21. Za istraživanja krajem 19. i početkom 20. st. i bibliografiju od Drugog svjetskog rata do danas vidi kod Martina Dubolnić Glavan, Civitas Aenona, primjer romanizacije liburnske općine, I-II, Doktorski rad, Zadar, 90, bilj. 244.

3 Giuseppe SABAlich, Guida archeologica di Zara, Zara, 1897.; Giovani SMIrICH, Arte retrospettiva; Il tempio di s. Donato in Zara, Emporium, vol. XIII, N. 73, Bergamo, 1901.; Mihovil ABRAmić et al., Fübrer durch das k. k. Staatsmuseum in S. Donato in Zara, Wien, 1912.; Giovani BersA, Guida storico-artistica di Zara, Catalogo del R. Museo di S. Donato, Trieste, 1926.; Rudolfo Valenti, Il Museo nazionale di Zara, Roma, 1932.; Mate Suić, Muzeji i zbirke Zadra, Zagreb, 1954.; Šime Batović, Julijan Medini, Janko Belošević, Vodič, Arheološki muzej u Zadru, Zadar, 1979.; Šime Batović, Mate SuIć, Janko Belošević, Nin, povijesni i umjetnički spomenici, Zadar, 1986.; Kornelija Appio Giunio et al., O Roma nobilis: Rim u Arheološkom muzeju Zadar: katalog stalnog postava rimske zbirke $=O$ Roma nobilis: Rome in the Archaeological museum Zadar: catalogue of the permanent exhibition of Roman antiquities, Katalozi i monografije, 18, Zadar, 2016. 
Drugog svjetskog rata Muzej u Svetom Donatu pretrpio je razaranje i pljačku tijekom koje su uništene inventarne knjige, materijal izmiješan, a najatraktivniji dio fundusa je ukraden. ${ }^{4} \mathrm{Za}$ suvremenu arheološku znanost tako je izgubljen cijeli korpus važnih informacija o dobro istraženim područjima poput Nina, ali i ostalih područja u zadarskom zaleđu. Podatci o uporabi ninskog "otoka“ i okolnog prostora za ukapanje tako su ostali nepotpuni i šturi, što je jedan od većih problema u razumijevanju tog aspekta života stare Enone.

Proučavajući relevantnu arheološku literaturu od kraja 19. st. te dostupnu muzejsku dokumentaciju i građu, a preko dokumentiranih nadgrobnih spomenika i latinskih natpisa, studiji ninskih nekropola pokušalo se pristupiti integralnoi prikupiti što veći korpus informacija. ${ }^{5}$ Prilikom definiranja prostorne distribucije dokumentiranih grobova primijenjene su metode arheologije krajolika, provedena je studija katastara, zračnih snimaka i lokalne toponimije istraživanog područja. Na području veličine $20 \mathrm{~km}^{2} \mathrm{u}$ ninskoj gradskoj okolici (Nin, Zaton, Privlaka i Vir) proveden je arheološki terenski pregled (2012. - 2013. g.) koji je rezultirao novim spoznajama o intenzitetu i obrascima naseljavanja te urbaniziranosti ruralnog krajolika u okolici grada. ${ }^{6}$ Prostorni podatci dobiveni terenskim pregledom uz upotrebu geoinformacijskih alata (GIS baza) obogaćeni su i informacijama prikupljenim istraživanjem Arhive dr. Luke Jelića pohranjene u Arheološkom muzeju u Splitu. ${ }^{7}$ Tako je, usprkos navedenim problemima, dobivena približna slika o rasteru gradskih nekropola rimske Enone (Sl. 1) i bogatstvu građe koju su sadržavale.

4 Prilikom povlačenja talijanske vojske iz okupiranog Zadra 1943. g., iz Arheološkog muzeja u Zadru odnesena je većina najvrjednije građe (kao i dio inventarnih knjiga), od čega značajan dio otpada na nalaze iz Nina. Znatan dio preostale građe naknadno je stradao u bombardiranju Zadra 1943. 1944. g. Vidi pregledno: Šime BATović, 150 godina Arheološkog muzeja u Zadru, Katalog izložbe, Zadar, 1982.; Antonija MLI котA, MFAA - dosje Zadar, nove spoznaje o umjetninama odnesenima iz Zadra u Italiju za vrijeme Drugog svjetskog rata, Asseria, 10, Zadar, 2012.

5 Za metode istraživanja vidi kod: M. Dubolnić Glavan, Civitas Aenona, primjer romanizacije liburnske općine, I, 2 - 8, Dodatak 2.

6 Martina Dubolnić Glavan, Grad Nin: šire područje - rekognosciranje, Hrvatski arheološki godišnjak, 9, Zagreb, 2012., 610 - 613; Martina Dubolnić Glavan, Terenski pregled i kartiranje arheološke baštine Grada Nina tijekom 2012. i 2013. godine, Stručna studija, 2013., Grad Nin, TZ Grada Nina, Ministarstvo kulture RH, Konzervatorski odjel Zadar, Zadar, 107; Martina Dubolnić Glavan, Igor Kulenović, Neda Kulenović Ocelić, Sites Twice Removed: a Case Study from Roman Dalmatia, Recent Developments in Archaeometry and Archaeological Methodology in Southeastern Europe, Cambridge Scholars Publishing, 2019. in press.

7 M. Dubolnić Glavan, Civitas Aenona, primjer romanizacije liburnske općine, I, 90 - 105, 162 - 167, Dodatak 2, Dodatak 3. Za proučavanje gradskih nekropola značajne su informacije o katastarskim česticama s kojih potječu nalazi pojedinih grobova, kao i popis najvrjednijih predmeta s ninskih nekropola smještenih početkom 20. st. u zadarskom Muzeju. 


\section{NEKROPOLE I NADGROBNI SPOMENICI RIMSKE ENONE}

Kontinuitet ukapanja na nekropolama Enone može se pratiti od ranog željeznog doba do kasne antike. Liburni su se pokapali u grobljima na ravnom i pod tumulima, no na ninskom je području dokumentiran mnogo veći broj grobova na ravnom, pa zaključujemo da je taj tip ukopa bio prevladavajući. Prakticiran je ritus inhumacije, u zgrčenom položaju, za odrasle uglavnom u kamenim škrinjama, a za djecu i u većim keramičkim posudama. ${ }^{8}$ Postupnim urastanjem Enone u rimski kulturni milje na području grada i okolice počinje prevladavati novi ritus pokapanja - incineracija - koji karakterizira ukop koštanih i pepeonih ostataka u kamenu, keramičku ili staklenu urnu (nekad u njihovoj kombinaciji) i prilaganje raznovrsnih grobnih priloga.

Prema podatcima dobivenim provedenim istraživanjima, može se govoriti o prostornoj distribuciji željeznodobnih grobova u odnosu na rimskodobne (S1. 1). ${ }^{9}$ Paljevinski grobovi zabilježeni su u blizini ili praktički kraj grobova s inhumiranim pokojnicima, prema čemu je vidljivo kako rimske nekropole izrastaju u neposrednoj blizini ili na mjestu onih ranijih. Podatci o prostornom rasporedu gradskih nekropola upućuju na zaključak da se proces tranzicije odvijao bez ikakvog diskontinuiteta, ${ }^{10}$ što je $s$ obzirom na društveno-političke okolnosti i očekivano.

Urne su zakapane direktno u zemlju bez arhitekture ili postavljane unutar manjih ili većih grobnih konstrukcija i grobnih zdanja. ${ }^{11}$ Tijela su spaljivana na lomači (ustrinum), što je dokumentirano istraživanjima na položaju Ždrijac. ${ }^{12}$

8 Šime BAtović, Arheološka iskapanja u Ninu, Ljetopis JAZU, knj. 63, Zagreb, 1959., 205 - 208, S1. 1-7; Šime, BATović, Istraživanja liburnskog naselja u Ninu 1969. godine, Diadora, 5, Zadar, 1970. 40 - 44; Zdenko BRUsIć, Nekropole liburnskih naselja Nina i Kose kod Ljupča, Histria antiqua, 8, Pula, 2002., 213 - 224.

9 M. Dubolnić Glavan, Civitas Aenona, primjer romanizacije liburnske općine, 93 - 94, 466 - 471, bilj. 253, Karta 1, Dodatak 3, br. 143-24, br. 144-26, 145-32, pregledno o povijesti istraživanja i položajima s kojih potječu predrimski grobovi na ravnom i pod humcima sa starijim bibliografskim referencama.

10 Vidi kod M. Dubolnić Glavan, Civitas Aenona, primjer romanizacije liburnske općine, I, 90 - 91, S1. 37.

11 Iz Nina potječu nalazi brojnih kamenih urni s kratkim natpisom uklesanim na poklopcu ili tijelu urne. Među imenima pretežu ona domaćeg ili moguće domaćeg podrijetla, vidi kod M. DubolNić Glavan, Civitas Aenona, primjer romanizacije liburnske općine, I, 95, kat. br. 22, 27, 28, 30, 33 - 35, 40, 45, Sl. 72, 75, 78 - 80, 86; Branka Nedved, Stanovništvo Zadra od 1. do 3. stoljeća (I. dio), Diadora, 14, Zadar, 1992., 134. Čak 11 primjeraka urni s natpisom u Arheološkom muzeju u Zadru potječe iz Enone, a jedna nepoznatog podrijetla vjerojatno je također iz Enone.

12 Š. BAtović, Arheološka iskapanja u Ninu, 208 - 209; M. SUIĆ, Antički Nin (Aenona) i njegovi spomenici, 65. 


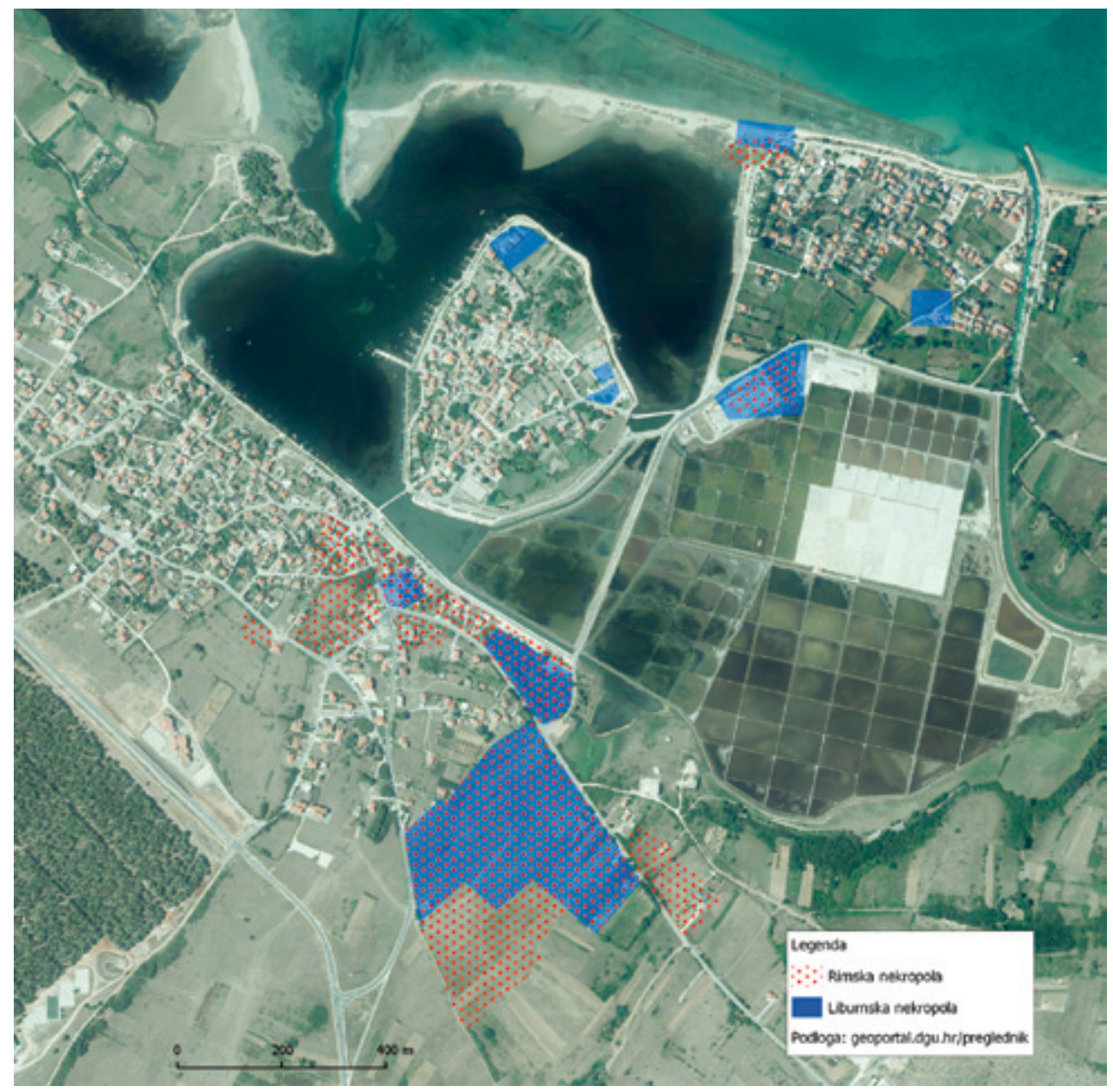

SLIKA 1. Raster predrimskih i rimskih nekropola Enone (preuzeto iz M. Dubolnić Glavan, Civitas Aenona, 2015., 97, S1. 37)

Instalacije za pohranu spaljenih kostiju i pepela s vremenom će se kao kružni ili kvadratni recipijenti pojaviti i unutar nadgrobnih spomenika, osobito tzv. liburnskih cipusa i nadgrobnih ara..$^{13}$

Imajući u vidu prostorni odnos željeznodobnih i rimskih grobova, kao i činjenicu da su rimske komunikacije uglavnom slijedile trase predrimskih,

13 Pregledno: Dražen Maršić, Funerary Altars of Roman Iader - The study of the topical character and function of funerary altars of the Roman province of Dalmatia, Sepulkralna skulptura Zapadnog Ilirika i susjednih oblasti u doba Rimskog carstva (ur. N. Cambi, G. Koch), Split, 2013., 394 i d., Sl. $6-9$. 
konstatacija da su se nekropole grada formirale u skladu s rimskom urbanističkom praksom načelno stoji, ali je velikim dijelom riječ i o naslijeđu iz ranijeg perioda. ${ }^{14}$ Rimska faza zasigurno je donijela značajnu resistematizaciju i nove tipove funerarne arhitekture i umjetnosti, kako to npr. zorno pokazuje situacija u susjednom Nadinu. ${ }^{15}$

Glavne rimskodobne nekropole razvile su se duž cesta koje su od gradskih vrata danas znanih kao „Donja“ i „Gornja“ vrata (koja nisu direktno na mjestu antičkih!) vodila u ager. ${ }^{16}$ Iz pravca južnih ili Donjih vrata, vjerojatno preko mosta, jedna je komunikacija vodila jugozapadno, prema glavnoj gradskoj luci u uvali Dražnik u Zatonu. Druga se od nje odvajala prema zapadu u smjeru Privlake i Vira. $S$ trasom tih komunikacija mogu se povezati nalazi grobova na širem području oko crkve sv. Jurja u Klanicama. ${ }^{17}$ Druga je važna komunikacija išla prema jugoistoku u smjeru današnjih Ninskih stanova i u predjelu zaseoka Duševići skretala na jug prema Jaderu. Taj je potez najbolje potvrđen nalazima željeznodobnih i rimskih grobova. ${ }^{18}$

Proučavanjem arhivske građe iz Ostavštine dr. Luke Jelića dobiveni su dragocjeni podatci o nalazima željeznodobnih i rimskih grobova te o rezultatima prvih arheoloških istraživanja provedenih na spomenutom području koncem 19. i početkom 20. st. Podatci o nalazima posljednjih grobova u smjeru jugoistoka vežu se uz položaj Sipin Stan sa sjeverne strane današnje ceste Nin - Žerava te uz položaje Zgon, Dugača i Praulje s južne strane iste ceste. ${ }^{19}$

Vođeni prometnom logikom, dva bismo segmenta mogli u prvi mah protumačiti kao dvije nekropole - jugozapadnu i jugoistočnu - ali oni gotovo sigurno pripadaju jednoj, u dva smjera razgranatoj ,južnoj nekropoli“ ukupne duljine preko $1 \mathrm{~km}$. Ta nekropola razvijena s južne strane grada je čini se bila najvažnija i najveća nekropola Enone.

14 Vidi kod M. Dubolnić Glavan, Civitas Aenona, primjer romanizacije liburnske općine, 491.

15 Sineva Kukoč, Nadin - liburnski kult mrtvih: istraživanja 2004.-2006., 2009., Asseria, 7, Zadar, 2009., 11 i d., osobito 52 i d., Sl. 29 i 31 (slika i tlocrt cele I na kojima se sjajno uočava odnos ranijih liburnskih konstrukcija i onih ranorimskih, s tipično rimskim rješenjem pozicioniranja glavnog spomenika bliže pročelju grobnog areala i cesti do njega).

16 Položaj nalaza predrimskih i rimskih grobova vidi još u: Janko BELošEvić, Materijalna kultura Hrvata od 7. do 9. stoljeća, Zagreb, 1980., 23; Janko BelošEvić, Starobrvatsko groblje na Ždrijacu u Ninu, Zadar, 2007., 508; Z. Brusıć, Nekropole liburnskih naselja Nina i Kose kod Ljupča, 214.

17 M. Dubolnić Glavan, Civitas Aenona, primjer romanizacije liburnske općine, I, 162 - 165 , Dodatak 2, Karta 1 - 2, br. 145-32, 146, 147,

18 M. Dubolnić Glavan, Civitas Aenona, primjer romanizacije liburnske općine, I, 87 - 92 , Dodatak 2.

19 M. Dubolnić Glavan, Civitas Aenona, primjer romanizacije liburnske općine, I, 90 - 92 , Dodatak 2. 
Paljevinski grobovi koji potvrđuju postojanje još jedne ili dviju ranorimskih nekropola otkriveni su i sa sjeverne i sjeveroistočne strane grada na položajima Ždrijac i Solana, ali u manjem broju u odnosu na liburnske. ${ }^{20}$ Iz smjera antičkih „Gornjih vrata“ komunikacija je vodila u smjeru istoka $\mathrm{k}$ prostoru današnje Solane. No kako je to područje recentno devastirano izgradnjom, o rasteru i duljini nekropole ne može se ništa pouzdanije reći. Indikativni su podatci L. Jelića o slučajnim nalazima rimskih grobova uz komunikaciju u smjeru mjesta Grbe prema istoku. ${ }^{21}$ Budući da se nekropola prostirala istočno od grada, možemo je uvjetno nazivati ,istočnom nekropolom“.

Grobovi otkriveni na položaju Ždrijac dokazuju postojanje mjesta za ukop i sjeverno od grada. Takva prostorna distribucija nalaza grobova može se interpretirati dvojako: kao zasebna (sjeverna) nekropola, ali i ogranak (sjeverozapadni produžetak) „istočne“ nekropole. Navedene su nekropole bile istovremeno u uporabi, u ranocarskom razdoblju sasvim sigurno, a vjerojatno i u kasnijim stoljećima. Za rekonstrukciju nekadašnjeg paleokrajolika svakako je značajna i hidrografska situacija u okolici Nina (smjer toka rijeke Ričine), što je direktno vezano uz pitanje spoja sjeverne strane ninskog „otoka“ i pješčanog jezičca Ždrijaca, odnosno kopnenog položaja grada. ${ }^{22}$

$\mathrm{O}$ arhitekturi i uređenju gradskih i izvangradskih nekropola ne postoje egzaktni građevinski podatci. Razumno je pretpostaviti da su mjesta za ukop pokojnika bila izgrađena i organizirana slično onima u Jaderu, Argiruntu, Saloni ili drugdje. Veći segmenti bili su organizirani kao grobni areali, nekada i hortikulturno uređeni (hortus), koje su pak odvajali pristupni putovi (itinerum). Glavna „jedinica“ namijenjena pokapanju bila je obiteljska parcela - grobno mjesto (locus). U vrijeme prevlasti incineracije na grobljima su se uobičajeno nalazila i brojna mjesta za spaljivanje pokojnika (ustrinum).${ }^{23}$ Nekada su termini locus i hortus sinonimi za grobni areal, ali s očitom razlikom u veličini i imovinskopravnoj situaciji. Jedan hortus mogao je sadržavati veći broj lokula, ali je isto tako

20 M. Dubolnić Glavan, Civitas Aenona, primjer romanizacije liburnske općine, 92, Dodatak 2, Karta 1, br. 143-25, 144-26.

21 M. Dubolnić Glavan, Civitas Aenona, primjer romanizacije liburnske općine, 92, Dodatak 2.

22 Z. BRusić, Nekropole liburnskih naselja Nina i Kose kod Ljupča, 222; Detaljnije o geomorfologiji kod M. Dubolnić Glavan, Civitas Aenona, primjer romanizacije liburnske općine, 13 - 16, 20.

23 Za Salonu vidi u: Nenad CAмвi, Salona i njene nekropole, Radovi Filozofskog fakulteta u Zadru, 25 (12), 1986., 65 i d., 90 i d. (= Salona und seine Nekropolen, Römische Gräberstraßen. Selbstdarstellung - Status - Standard, Kolloquium in München vom 28. bis 30. Oktober 1985, ur. H. von Hesberg, P. Zanker, München, 1987., 253 i d., 273 i d; Za Jader vidi u: Smiljan GLuščEvić, Zadarske nekropole od 1. do 4. stoljeća. Organizacija groblja, pogrebni obredi, podrijetlo, status i standard pokojnika, Doktorski rad, Zadar, 2005., 263 i d. 
cijeli hortus mogao biti locus jedne obitelji. U radu će biti korišten termin „grobni areal“ jer po našem mišljenju bolje definira obzidani grobni prostor i ne uvodi u raspravu složene imovinsko-pravne odnose (poput njemačke riječi Grabbezirk).

Najuglednije obitelji zacijelo su imale grobna mjesta i monumentalne spomenike u prvom redu nekropole do glavne komunikacije. Status i podrijetlo glave obitelji, kao i suvremeni modni trendovi, diktirali su izbor središnjeg nadgrobnogspomenika(monumentum). Onje najčešće biou formi monumentalne stele, nadgrobne are, monumentalnog zdanja, a kasnije i sarkofaga. ${ }^{24}$ Većina pokojnika ipak je mogla biti sahranjena anonimno, bez nekog biljega na površini, osobito oni nižeg društvenog statusa. ${ }^{25}$

Prema podatcima iz literature na nekropolama rimske Enone nije istražen nijedan grobni areal ni neki njegov znatniji dio. Za rekonstrukciju njihova izgleda možemo koristiti tek rijetke natpise $s$ navodom dimenzija grobnih prostora (in fronte pedes „tot“, in agro pedes „tot“), a djelomice i karakter pojedinih nadgrobnih spomenika.

Terminacijske formule javljaju se na svega tri nadgrobna spomenika pronađena u širem arealu gradskog središta. Na natpisnoj ploči Lucija Barbija Krispa i Kvinta Barbija Rufa (CIL 3, 2979 p. 1037 ad n. 2979) donosi se mjera 35 x 10 stopa. Na spomeniku (CIL 3, 2986) nepoznate pripadnosti donesena je mjera 20 x 20 stopa, a na steli Gaja Julija Atika $10 \times 15$ stopa. ${ }^{26}$ Dimenzije pročelja (in fronte) tako variraju od minimalno 10 do čak 35 stopa (cca 3 - 10,5 m), a dubina areala (in agro) 10 - 20 stopa (cca $3-6 \mathrm{~m}$ ). U slučaju prvog navoda riječ je o poprečno izduženom pravokutniku, u drugom o kvadratu, a u trećem o blago izduženom pravokutniku. Najskromniji areal zauzimao je površinu od oko $13,5 \mathrm{~m}^{2}$, a najveći $36 \mathrm{~m}^{2}$, čime se potonji približava arealima istraženima na nekropoli Argirunta. ${ }^{27}$ Zanimljivo je da sve tri poznate dubine grobnih areala donose različite mjere.

24 N. Cамвi, Salona i njene nekropole, 1986., 105 (= Salona und seine Nekropolen, 1987., 272 273); S. GluščEvić, Zadarske nekropole od 1. do 4. stoljeća, 280 i d. Od ukupno 24 spomenika koji sadrže informacije o grobnim prostorima na nekropolama Jadera 6 ih pripada stelama, 3 titulima, 4 liburnskim cipusima, dok za 10 spomenika tipološka pripadnost nije poznata.

25 S. GluščEvić, Zadarske nekropole od 1. do 4. stoljeća, 283.

26 Mate SuIć, Neobjelodanjeni rimski natpisi iz sjeverne Dalmacije (Inscriptiones Dalmatiae Septemtrionalis nondum editae), Vjesnik za arheologiju i historiju dalmatinsku, LIV, Split, 1952., 208, br. 8; Vidi M. Dubolnić Glavan, Civitas Aenona, primjer romanizacije liburnske općine, I, 93, 276 - 281, Kat. br. 7, 14, 42 .

27 Mihovil Abramić, Anton Colnago, Untersuchungen in Norddalmatien, Jahreshefte des Österreichischen archäologischen Instituts, 12, Wien, 1909., 52 i d.; S. GLuščEvić, Zadarske nekropole od 1. do 4. stoljeća, 264 - 265, bilj. 108; Martina Dubolnić, Argyruntum i njegov teritorij u antici, Radovi Zavoda za povijesne znanosti Hrvatske akademije znanosti i umjetnosti $u$ Zadru, 49, Zadar, 2007., 29. 
Prema tome, samo temeljem podataka s nadgrobnih natpisa, bez istraživanja, ne može se govoriti o nizu grobnih areala iste dubine koji su pratili cestu.

Na portretnoj steli obitelji Ennius iz obližnjeg Podvršja navodi se još jedan grobni areal veličine oko $15 \mathrm{~m}^{2}(12 \times 14$ stopa $=$ cca 3,6 $\times$ 4,2 m). Mjesto otkrića dijelova te stele potvrđuje već poznatu situaciju - terminacijska formula uglavnom se vezuje za spomenike koji su stajali u urbanom funerarnom kontekstu, ali je ipak poznata i na spomenicima s prostora agera. ${ }^{28}$ To upućuje na zaključak da su na rimski način uređeni grobni areali postojali i u ruralnom ambijentu. ${ }^{29}$

$\mathrm{O}$ arhitekturi i monumentalnosti enonskih nekropola indirektno govore i spomenici koji su ih krasili. ${ }^{30}$ Jedan od zastupljenih tipova spomenika, u širokoj uporabi tijekom 1. st. po Kr., su i portretne stele. Arhitektonski kontekst stela - nosača portreta ponajprije treba tražiti po sredini pročelja areala ili $u$ njegovu središtu. Kako pripadajući natpisi često nisu sačuvani (osim na steli Enija iz Podvršja), pojedinosti nam ostaju nepoznate. Nadgrobni spomenik sevira Augustala Gaja Tulija Ursiona, poznat samo iz rukopisne predaje (CIL 3, $2978=10018$, spomenik je okarakteriziran kao ara lapidea), jedini je sigurni primjerak nadgrobne are, tipa luksuznog nadgrobnog spomenika koji je u istoj ulozi zamijenio monumentalne stele. ${ }^{31}$ Are su mogle funkcionirati i kao urne $u$ obliku oltara. Ursionova ara je iz 2. ili 3. stoljeća po Kr., no omogućuje realnu pretpostavku da su se are u Enoni pojavile mnogo ranije. Usporedimo li situaciju u susjednom Jaderu i Aseriji, one su se i u Enoni mogle pojaviti najkasnije na početku razdoblja standardizacije krajem 1. i u prvoj pol. 2. st. ${ }^{32}$

Nešto je bolje dokumentirana pojava građevina u čija su pročelja bili uzidani reljefi s portretima pokojnika koji su se do danas jedini očuvali. Taj tip spomenika izgledom podsjeća na stelu, ali se od nje razlikuje poprečnom koncepcijom, višefiguralnošću, izvedbom natpisnog polja (često zasebnom) i instalacijama

28 Dražen MARšić, Rekonstrukcija nadgrobne stele obitelji Ennius iz Enone, Histria antiqua, 18-2, Pula, 2009., 35 - 41; M. Dubolnić Glavan, Civitas Aenona, primjer romanizacije liburnske općine, I, 93, kat. br. 41 .

29 N. Самві, Salona i njene nekropole, 1986., 98 i d. (= Salona und seine Nekropolen, 1987., 269 i d.).

30 Vidi sumarno kod M. Dubolnić Glavan, Civitas Aenona, primjer romanizacije liburnske općine, I, $95-105$.

31 Pregledno: Nenad Cамвi, Pregled razvoja nadgrobnih spomenika u rimskoj Dalmaciji, Sepulkralna skulptura Zapadnog Ilirika i susjednih oblasti u doba Rimskog carstva, ur. N. Cambi - G. Koch, Split, 2013., 25 i d., Sl. 45 i d.

32 Jader: D. MARšıć, Funerary Altars of Roman Iader, 390 i d., sl. 4, 6, 9a-b, 11 - 12, 409 i d., Kat. 1 6; Aserija: Dražen MARšıć, Aserijatske nadgrobne are, Asseria, 3, Zadar, 2005., 25 i d., Kat. 1 - 5, Sl. 1 - 10. Usp. i prethodnu bilješku. U Jaderu se are pouzdano pojavljuju najkasnije od Klaudijeva doba, a u Aseriji barem od flavijevskog doba. 


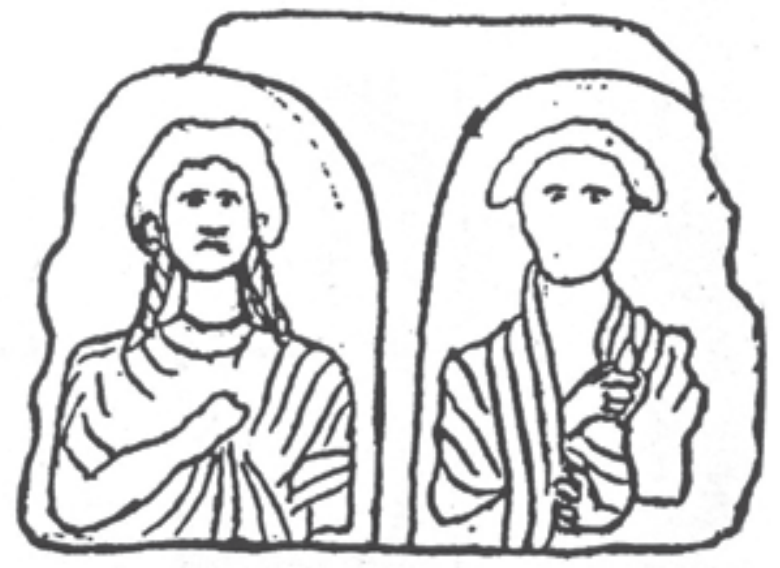

SLIKA 2. Ugradbeni reljef iz Enone na crtežu Mijata Sabljara (preuzeto iz: D. Maršić, Ugradbeni i gradevni portretni reljefi u Histriji i Dalmaciji, 2009., S1. 5)

za ugradnju. ${ }^{33}$ Dva sigurno atribuirana enonska ugradbena reljefa potječu iz približno istog vremena, malo prije ili oko sredine 1. st. po Kr., što implicira da se najkasnije od toga vremena na nekropolama Enone uzdižu i monumentalna grobna zdanja.

Osobito je važan reljef poznat preko crteža Mijata Sabljara (Sl. 2) i manjeg fragmenta koji je preostao u Arheološkom muzeju u Zadru (Sl. 3). Taj reljef ima direktne usporedbe u jedina dva in situ sačuvana reljefa toga tipa u gradu Rimu, kao i nešto mlađem reljefu iz Lapidarija na susjednom otoku Rabu. ${ }^{34}$ Unutar izduženog pravokutnog bloka s polukružnim nišama prikazivao je pojedinačne portrete žene i muškarca, a možda i još ponekog pokojnika.

Drugi je reljef znatno kompleksnije izrade i blago trapezaste forme (Sl.4). Dva para portreta unutar širokih polukružnih niša i brojne instalacije jasno pokazuju da je bio dio neke složene konstrukcije. ${ }^{35}$ Kod oba reljefa izostaju natpisi, koji su očito bili zasebno izrađeni u obliku natpisnih tabula.

33 Pregledno o fenomenu „ugradbenih portretnih reljefa“ s referentnom stranom i domaćom literaturom: Dražen MARšıć, Ugradbeni i gradevni portretni reljefi u Histriji i Dalmaciji, Arheološki muzej Zadar, Zadar, 2009., 15 i d.

34 Analiza enonskog reljefa: D. MARšı́, Ugradbeni i gradevni portretni reljefi u Histriji i Dalmaciji, 31 i d., S1. 5, 78 i d., Kat. A11, T. 7/1. O tipološkoj (formativnoj) podudarnosti toga primjerka, onoga u rapskome Lapidariju i reljefa iz Rima usporedi: Dražen MARŠić, Ugradbeni nadgrobni reljefi Arbe, Izdanja Hrvatskog arheološkog društva, 30 (Istraživanja na otocima), Zagreb, 2015., 19 - 21, Sl. 1.

35 Detaljna analiza: D. MARšıć, Ugradbeni i gradevni portretni reljefi u Histriji i Dalmaciji, 32, 79 i d., Kat. A12, T. $7 / 2$. 


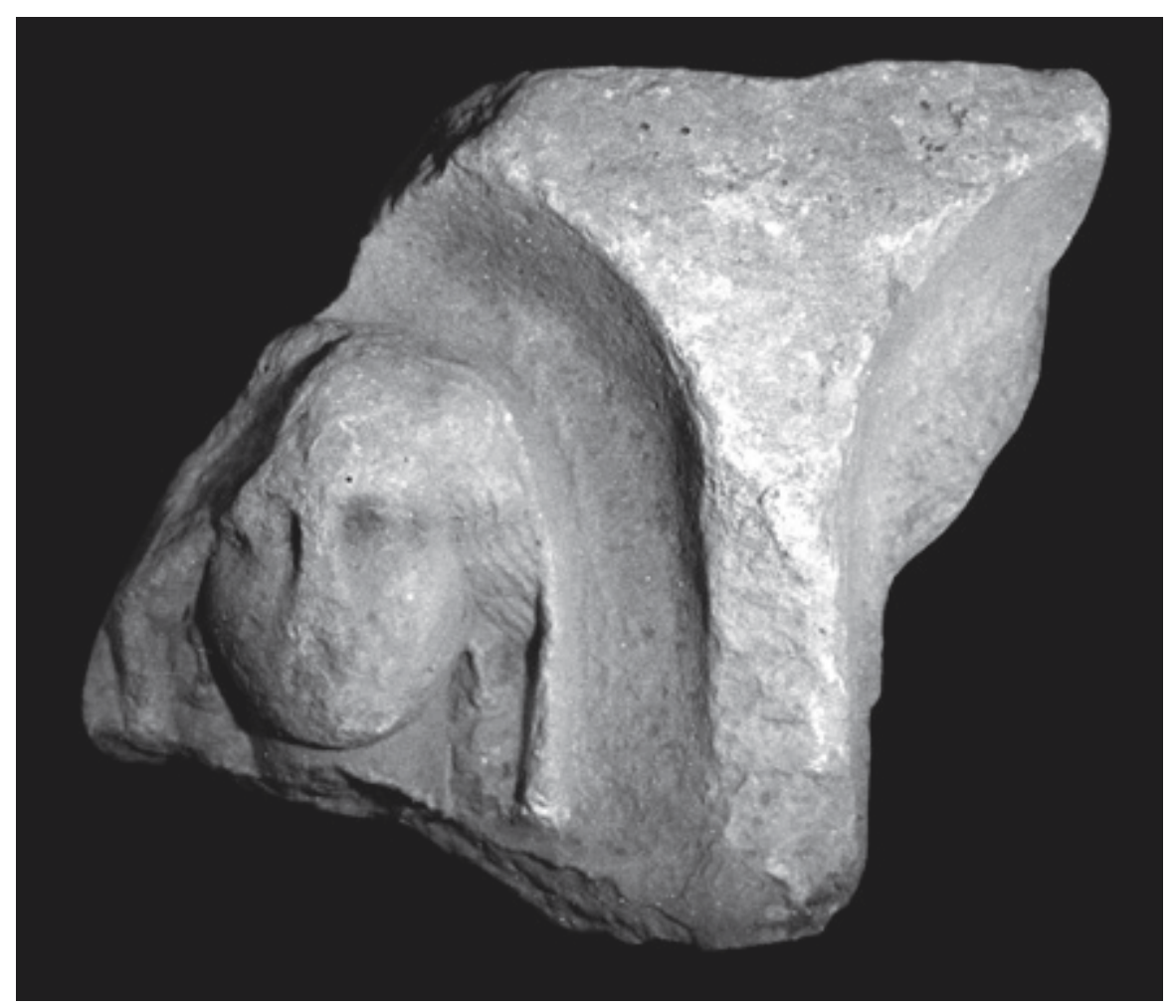

SLIKA 3. Fragment ugradbenog reljefa s crteža Mijata Sabljara u Arheološkom muzeju Zadar (preuzeto iz: D. Maršić, Ugradbeni i gradevni portretni reljefi u Histriji i Dalmaciji, 2009., T. 7/1)

Arhitekturi grobnih areala i dekoraciji pojedinačnih spomenika pripada i šest skulptura sfingi. ${ }^{36} \mathrm{U}$ funerarnom kontekstu sfinge obično imaju apotropejsku ulogu čuvara groba i besmrtnih duša pokojnika. Skulpture sfingi mogle su stajati u paru na uglovima grobnih areala, u funkciji akroterija stela i kompozitnih spomenika, poklopaca urni, ali i u sklopu kruništa ili podija

36 M. Dubolnić Glavan, Civitas Aenona, primjer romanizacije liburnske općine, I, 102 - 104, S1. 52 - 54; Kao dekorativne elemente nadgrobnih spomenika, ninske sfinge spominje i J. Bersa u vodiču kroz zadarski muzej u Svetom Donatu, vidi G. Bersa, Guida storico-artistica di Zara, Catalogo del R. Museo di S. Donato, Trieste, 1926., 140 - 141, br. 146, 150; Integralnu objavu šest skulptura sfingi iz Arheološkog muzeja u Zadru vidi u: Nikola CeSAri K, David ŠTrmelJ, Sfinge iz Enone, Diadora, 29, Zadar, 2015., $79-84$, Sl. 1 - 18.

37 Najbliža su usporedba primjerci sfingi iz Pole datirani u prvu polovicu 1. st. po Kr., vidi kod Alka STARAC, Reljefni prikazi na rimskim nadgrobnim spomenicima u Arheološkom muzeju Istre u Puli, Monografije i katalozi 16, Pula, 2006., 33; Alka STARAC, Funerary Sculptures in Istria: Animal and Mythological Figures, Sepulkralna skulptura Zapadnog Ilirika i susjednih oblasti u doba Rimskog carstva (ur. N. Cambi - G. Koch), Split, 2013., 198 - 199, 206, Kat. 9 - 10, S1. 9. 


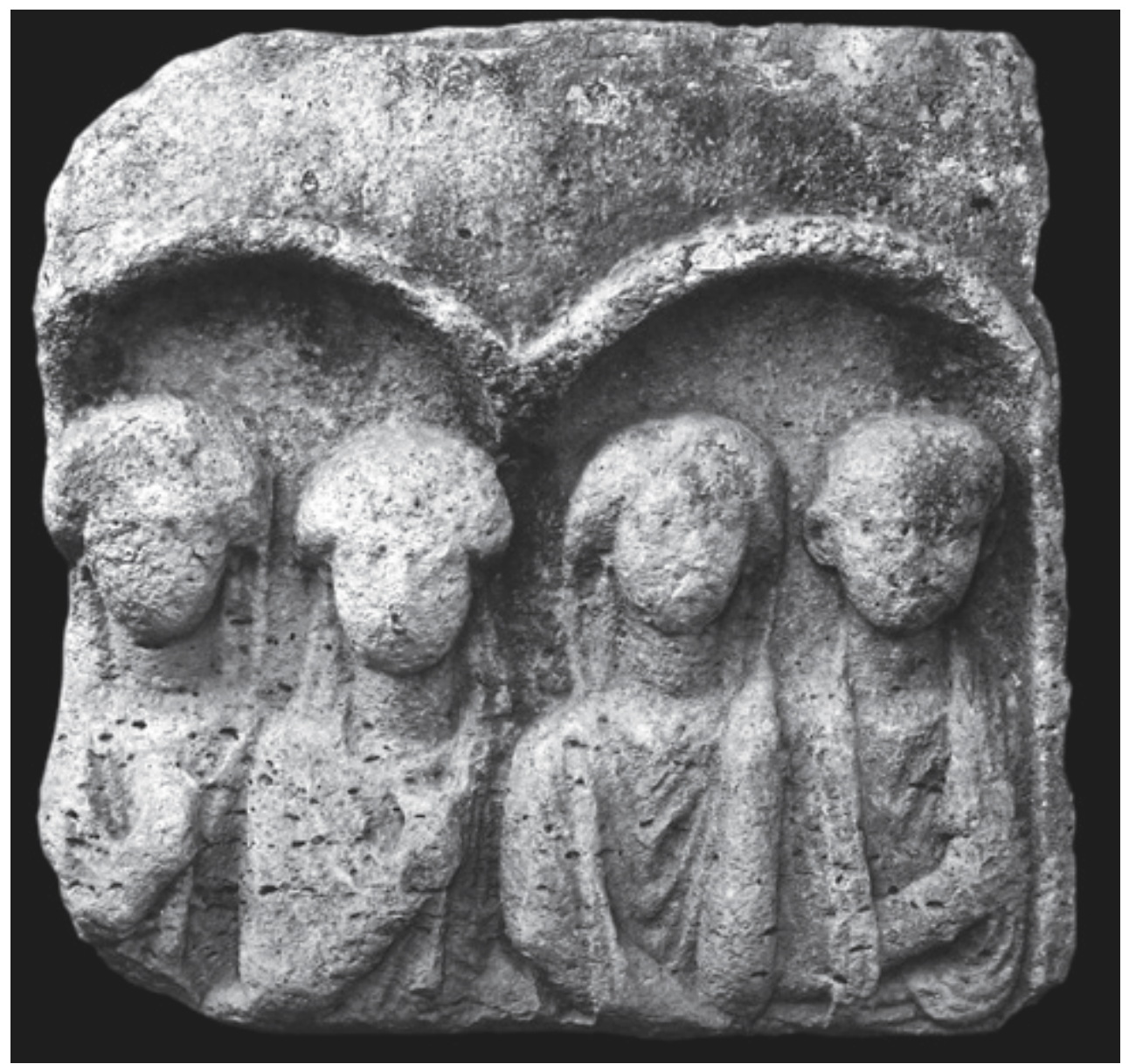

SLIKA 4. Ugradbeni reljef s prikazom četiri pokojnika iz Muzeja ninskih starina (Izvor: fototeka Arheološkog muzeja Zadar, preuzeto iz: D. Maršić, Ugradbeni i gradeuni portretni reljefi u Histriji i Dalmaciji, 2009., T. 7/2)

mauzoleja. ${ }^{37}$ Iako je riječ o primjercima problematičnog podrijetla, prilično pouzdani podatci o mjestu nalaza barem tri, ako ne i četiri primjerka dobiveni su pregledom Arhive dr. L. Jelića. Kao jedan od prvih istraživača ninskih groblja Jelić se osvrnuo i na nalaze spomenutih skulptura: „Pred Ninom na današnjoj zadarskoj cesti kod Ljuljevaca bilo je nekoliko monumentalnih grobnica. Djelomice su im podgradci još pod zemljom s bokova podrovani od ninskih starinarskih grobodera; česti monumentalnih natpisa jamče nam da su bile ovećih izmjera i ukusno arhitektonski dekorovane. Spomenuti ćemo samo 3 sirenska kipića od kojih jedan je od mješovitog sirensko-lavskog tipa što su 
dospjela u zadarski muzej Sv. Donat.“ Na drugom pak mjestu u bilješkama o nalazima sa spomenutih istraživanja Jelić navodi: „Sv. Donat, Sirene iz Nina - Knežev vrtal. Ima 4 komada. Neke imaju sirenski oblik, a neke opet donji dio lavskog tijela (sfinge?).“ ${ }^{38}$ Prema tome, skulpture sfingi otkrivene su kod Ljuljevaca i na Kneževu Vrtalu (toponimi se i danas koriste), na položajima u sklopu ,južne nekropole“. Navodi L. Jelića još jednom potvrđuju pretpostavku da je nekropola uz cestu prema Jaderu bila osobito raskošne arhitekture. Za kasniju je raspravu također važno i Jelićevo točno zapažanje da su neki natpisi monumentalnih razmjera stajali u zidovima tamošnjih grobnih areala i zdanja!

Ovdje navedeni primjeri stela, ara, ugradbenih reljefa i skulptura pokazuju da su nekropole Enone bile usporedive onima u Saloni ili Jaderu, ako ne i monumentalnije izvedbe. Samo je splet povijesnih okolnosti učinio da nažalost nisu bolje dokumentirane i poznate. U poglavljima koja slijede obrađeni su spomenici čije formativne ili tehnološke pojedinosti upućuju na pripadnost monumentalnoj grobnoj arhitekturi ili su fizički ostatci takve arhitekture.

\section{MONUMENTALNA GROBNA ARHITEKTURA I RELJEFNA SKULPTURA ENONE}

Na položaju Kulina u Vrsima, nekadašnjem dijelu ruralne aglomeracije antičke Enone, istraživanjima provedenim 1972. g. otkrivena je zanimljiva građevina čiji tloris i pripadajuća dokumentacija nisu nikada objavljeni. U međuvremenu je dokumentacija i zagubljena pa je otkriće poznato manjem dijelu arheološke javnosti. Istraživanja se sumarno spominju u kratkom izvješću voditelja Š. Batovića. Navodi se da je otkriveni objekt pravokutne osnove, dimenzija 7,62 x 5,12 m, s dobro očuvanom unutrašnjosti i ostatcima podnice, a dokumentirani su i temelji „prilaza“. Objekt je podignut je iznad kompleksa starijih građevina (!), unutar kojih su otkrivena dva ranorimska groba, dijelovi sarkofaga i stropova, kao i raznovrsna pokretna arheološka građa. Građevina je interpretirana kao rimski mauzolej. ${ }^{39}$

Kako smještaj tehničke dokumentacije $s$ istraživanja danas nije poznat, ovi navodi nisu bili provjerljivi pa su do sada često uzimani s rezervom. Pregledom

38 Arheološki muzej u Splitu (dalje AMS), Arhiva Luke Jelića, Reg. V-III, Grobnice i sadržina im, 95 - 96, Reg. V, sv. XV-2. Vidi kod M. Dubolnić Glavan, Civitas Aenona, primjer romanizacije liburnske općine, I, 103 - 104, bilj. 287.

39 Šime BAtović, Rad Arheološkog muzeja u Zadru od 1970. do 1972., Diadora, 6, Zadar, 1973., 280; Šime BATović, Sv. Jakov, Vrsi - rimska villa rustica i starohrvatsko groblje, Arheološki pregled, 22, Beograd, 1981., 87; Šime BATović, Ivan BATović, Zemljopisni i kulturno-povijesni pregled Vrsi, Zadarska smotra, XLII, br. 6, Zadar, 1993., 214 - 215, 223, T. 1- 17, T. 2 - 18. 
fototeke Arheološkog muzeja u Zadru pronađeno je nekoliko desetina fotografija nastalih tijekom istraživanja. ${ }^{40}$ Spomenuta fotodokumentacija za temu ovog istraživanja vrlo je važna pa smo odabrali četiri fotografije koje potvrđuju interpretaciju građevine kao mauzoleja i upućuju na njezin smještaj. Prva fotografija prikazuje zidane temelje objekta vidljive u cijelosti nakon čišćenja (S1. 5). Na drugoj fotografiji dobro se uočava ravni začelni zid s ostatcima na nj naslonjene arhitekture (Sl. 6), a na trećoj temeljni ostatci „prilaza“ građevini (Sl. 7). Četvrta fotografija (Sl. 8) prikazuje objekt u širem prostornom kontekstu: njegovu orijentaciju i smještaj uz morsku obalu te položaj u okviru tadašnje moderne stambene izgradnje. Taj podatak nije nevažan u kontekstu mogućnosti ponovne ubikacije objekta, njegove valorizacije i zaštite te provođenja revizijskih istraživanja.

Ostatci zidane konstrukcije vidljive na fotografiji prilaza (Sl. 7) otvaraju jedno važno pitanje: ima li prilaz možda dvije faze izgradnje i je li u njegovu slučaju riječ o konstrukciji stubišta ili još prije protironu (predvorju)? Na slici 5 jasno se uočava da se desni rub ulaza u građevinu podudara s linijom spoja zidova na desnoj strani prilaza pa mu se širina može dobiti projicirajući taj detalj i na suprotnu, lijevu stranu. U kakvom su odnosu zidovi prilaza, s fotografija je teško procijeniti. Na slici 7 vidljivo je da vanjski zid lijeve strane prilaza nije organski vezan sa zidom pročelja, no ostaje pitanje je li riječ o dvije građevne faze ili uobičajenom redoslijedu izgradnje. Zatečeno stanje također ne dozvoljava procjenu je li građevina imala prozore i je li unutrašnjost bila raščlanjena nišama (čini da to ipak nije bio slučaj). U širem arealu grobnice pronađeni su i rimski paljevinski grobovi. Prema Batoviću, objekt nije funkcionirao samostalno, nego kao dio veće rimske rustične vile (villa rustica) čiji su ostatci otkriveni u neposrednoj blizini (na 200 m udaljenosti), na položaju crkve sv. Jakova. ${ }^{41}$

Nemoguće je ne primijetiti da tloris objekta otkrivenog na položaju Kulina i odnos prema susjednoj ruralnoj arhitekturi dokumentiranoj kod obližnje crkve sv. Jakova frapantno podsjećaju na odnos mauzoleja i gospodarskog sklopa u Mulinama na otoku Ugljanu. ${ }^{42}$ Usporedive su i dimenzije dvaju mauzoleja, iako je ninski malo veći. Mauzolej u Mulinama također je koncipiran od jednostavne funerarne cele i predvorja. Cela je imala mozaički pod i oslikane ravne zidove, a u njezinu središtu otkriveno je kameno postolje s dnom sarkofaga, najvjerojatnije

40 Vidi kod M. Dubolnić Glavan, Civitas Aenona, primjer romanizacije liburnske općine, I, 101 102 , Sl. $50-51$.

41 Š. Batović, Rad Arheološkog muzeja u Zadru od 1970. do 1972., 280 - 281; Š. BAtović, Sv. Jakov, Vrsi - rimska villa rustica i starohrvatsko groblje, 85 - 90, T. $61-63$.

42 O mauzoleju: M. SUIĆ, Arheološka istraživanja u Mulinama na otoku Ugljanu, Ljetopis JAZU, knj. 64, Zagreb, 1957., 237 i d., Sl. 3 - 6, T. 4/2 - T. 6. 


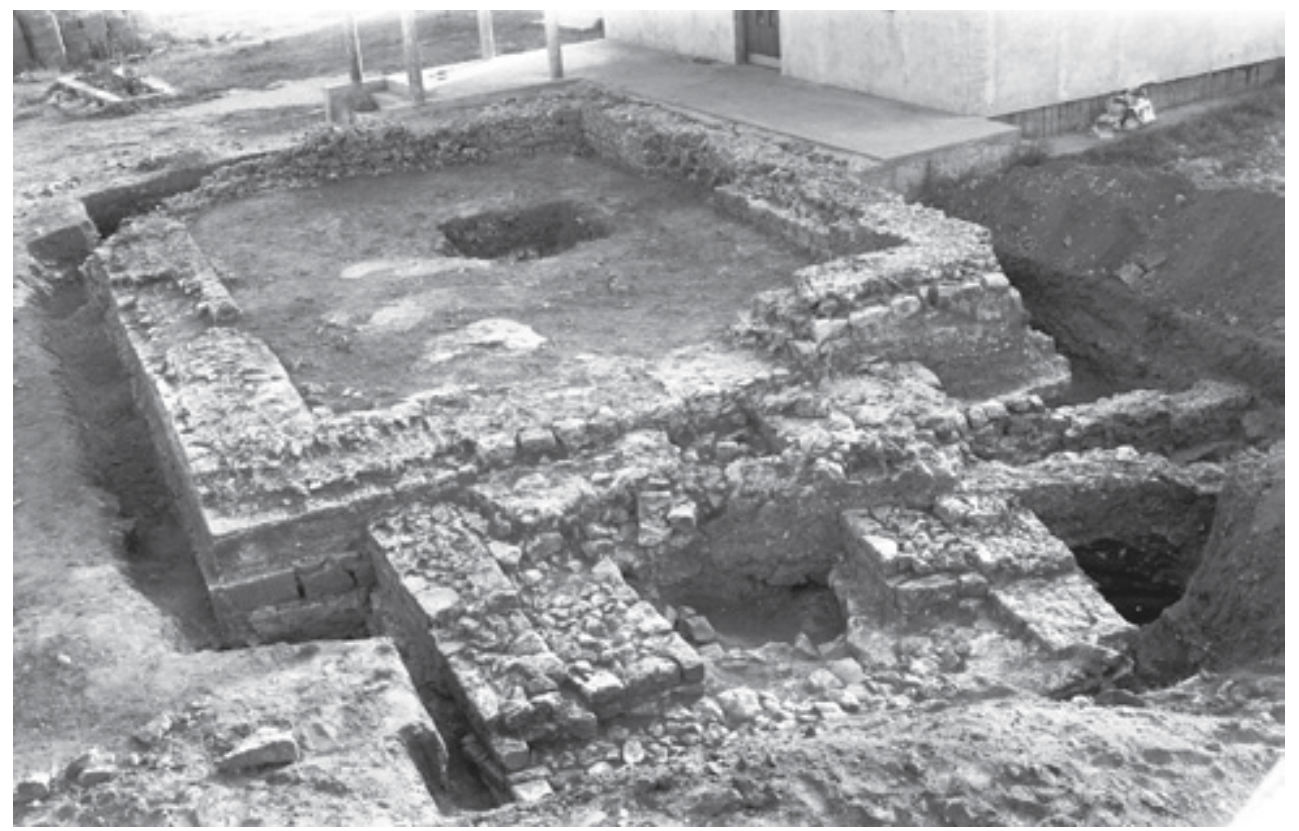

SLIKA 5. Pogled na mauzolej otkriven na položaju Kulina u Vrsima prilikom istraživanja 1972. (Izvor: fototeka AMZd)

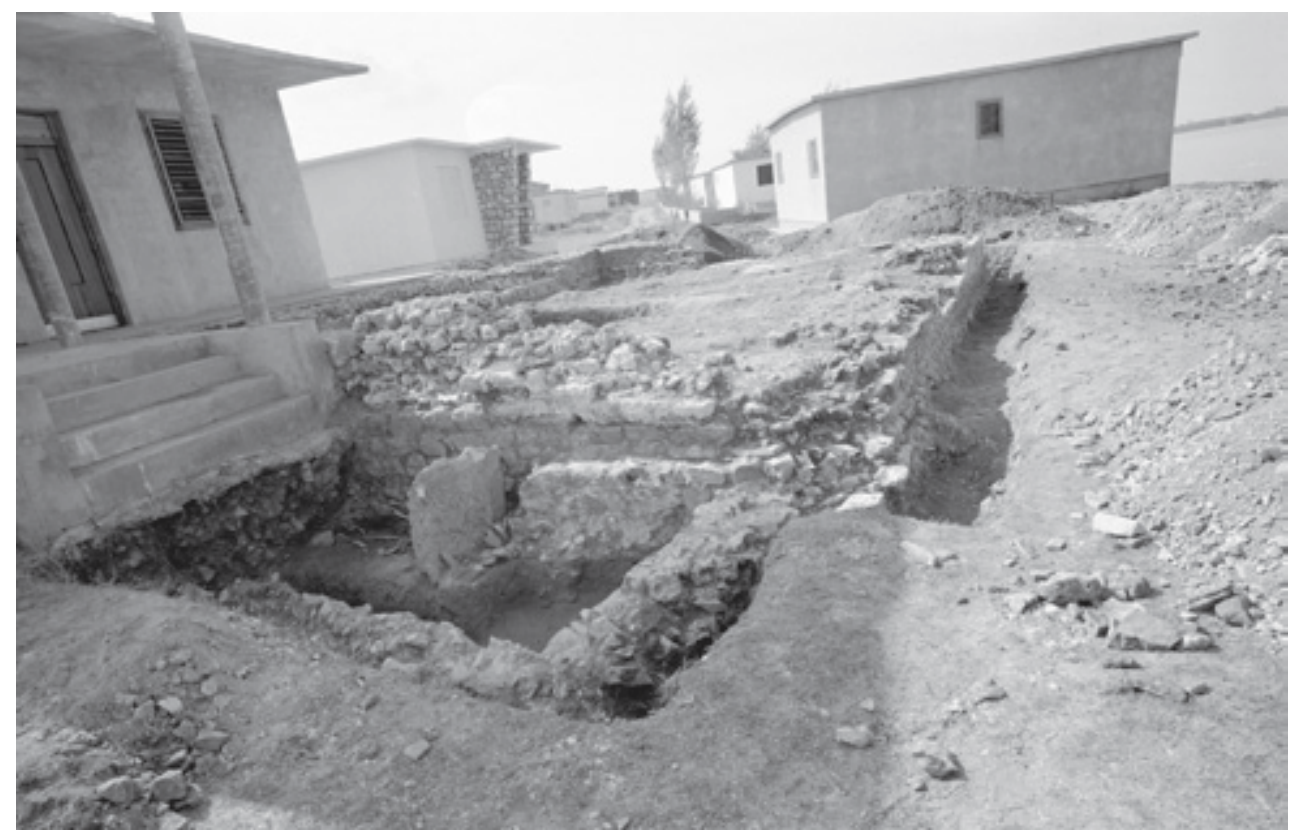

SLIKA 6. Pogled na začelje i susjednu arhitekturu mauzoleja na položaju Kulina (Izvor: fototeka AMZd) 


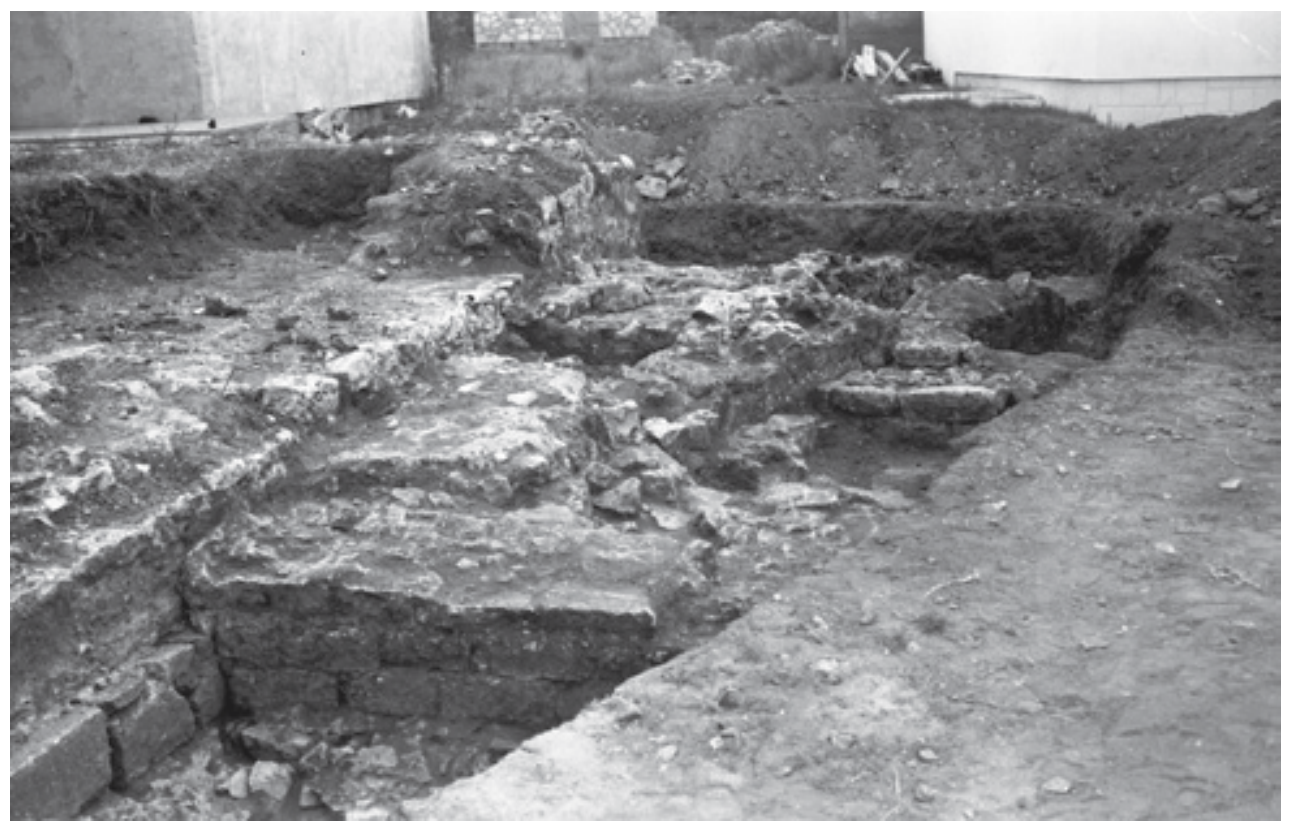

SLIKA 7. Pogled na prilazni dio mauzoleja na položaju Kulina (Izvor: fototeka AMZd, preuzeto iz M. Dubolnić Glavan, Civitas Aenona, 2015., 102, sl. 51)

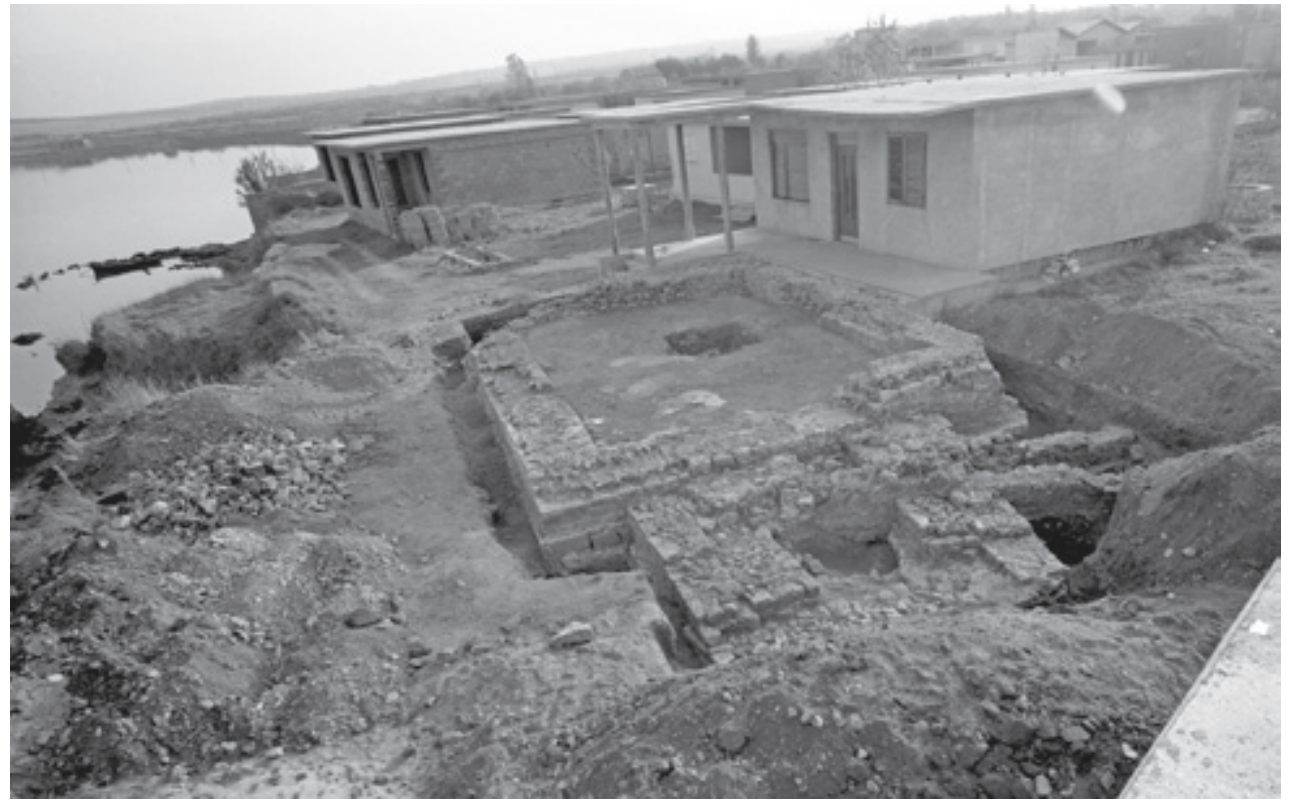

SLIKA 8. Pogled na arhitekturu otkrivenog mauzoleja i okolni krajolik (Izvor: fototeka AMZd) 
prvotnog vlasnika gospodarskog sklopa. Izgleda da je prilazni dio doživio promjene na način da su izvornoj konstrukciji protirona s dva stupića pridodana dva zidića umetnuta između pročelja i stupića. Građevina je prema M. Suiću imala bačvasti svod od sedrenih blokova, iz čega automatski slijedi zaključak da je krov bio zabatnog tipa s dvije krovne strehe (uključivši i protiron). Suglasni smo $s$ takvim prijedlogom i držimo ga jedinim mogućim. ${ }^{43}$ Štoviše, držimo da ga treba primijeniti i na objekt iz Kuline, o čemu će više biti riječi nešto kasnije. Ako je točna pretpostavka da su dvije građevine u osnovi istoga tipa, to bi bio prvi konkretniji trag jednog kasnijeg horizonta sepulkralnih građevina, nastalih u razdoblju od 3. ili 4. st. (Kulina) do najkasnije početka 5. st. (Muline). Ove su se građevine čini se znatno razlikovale od prijašnjih zdanja iste namjene.

U lapidariju Muzeja ninskih starina u Ninu izložen je kameni fragment ovećeg elementa dvostrane izrade koji je u inventarnoj knjizi Muzeja tipološki opredijeljen kao „stela“, a kao mjesto pronalaska naveden je položaj Dvorine (igralište) 1997. g. ${ }^{44}$ To bi značilo da je spomenik pronađen u sekundarnom položaju, vjerojatno uzidan $u$ gradske bedeme. U raspravi koja slijedi dokazat ćemo da je riječ o građevnom natpisu, tj. natpisu u funkciji trabeacije monumentalne grobne arhitekture. Metalna rešetkasta konstrukcija na koju je spomenik položen omogućuje pogled na prednju stranu s latinskim natpisom, ali priječi direktan pogled na jednu bočnu i donju stranu (Sl. 9).

Od elementa je sačuvan lijevi rub, odnosno ugao, u punoj visini nekadašnjeg natpisnog polja. Visina mu je 0,63 m, maksimalna širina (duljina) $0,57 \mathrm{~m}$, a najveća dubina $0,32 \mathrm{~m}$. Na prednjoj strani nalaze se ostatci natpisa, a na lijevoj bočnoj strani isklesane su od dna prema vrhu tri fascije (vis. $24 \mathrm{~cm}$ ), cyma reversa profil (vis. $4,5 \mathrm{~cm}$ ) i friz ukrašen vegetativnim uzorkom (zacijelo akantom) koji završava četverolisnom polupalmetom (vis. $34 \mathrm{~cm})(S 1.9,10)$. Drugim riječima, element $s$ jedne strane funkcionira kao natpisna tabula, a $s$ druge strane kao arhitrav i friz (trabeacija) monolitne izrade. Blizu njihova spoja, na gornjoj strani elementa, nalazi se četvrtasti utor (dim. 4 x $4 \mathrm{~cm}$, dubine $3 \mathrm{~cm}$ ), do kojega od stranice $s$ natpisom vodi uski kanal (duljine $11 \mathrm{~cm}$ ), nesumnjivo za lijevanje kipućeg olova (Sl. 11). Na fotografiji spomenika izrađenoj prije njegova izlaganja u lapidariju (Sl. 12) uočava se jedan manji utor i na donjoj ravnoj stranici (udaljen od lijevog ruba $16,5 \mathrm{~cm}$ i od prednje plohe s natpisom $8 \mathrm{~cm}$ ). Pogled na donju stranu spomenika danas priječi željezna konstrukcija

43 Jedino protiron nije morao neophodno imati krov zabatnog oblika, nego je mogao biti riješen u obliku jedne krovne strehe.

44 Fragment je zaveden pod inventarnim brojem MNS654. Vidi kod M. Dubolnić Glavan, Civitas Aenona, primjer romanizacije liburnske općine, I, 230, 282, S1.77, natpis kat. br. 54. 


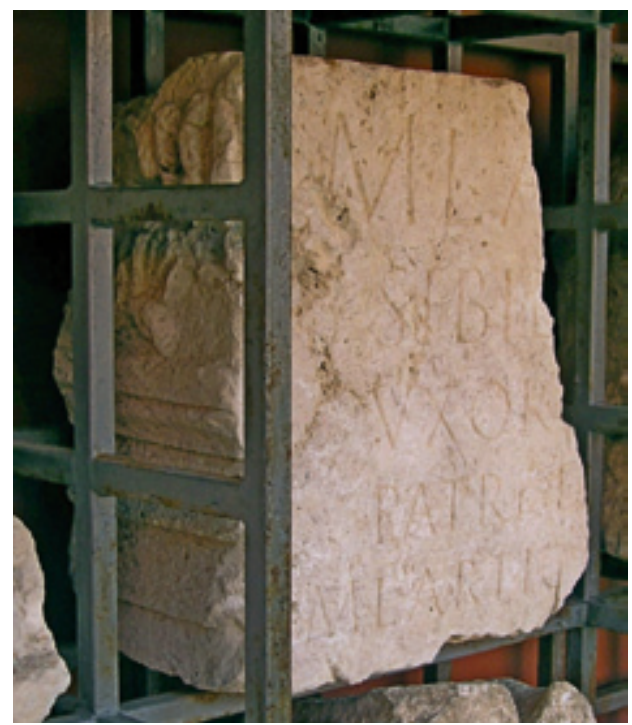

SLIKA 9. Pogled na ugaoni dio elementa trabeacije s natpisom obitelji Lartius (foto: autori)

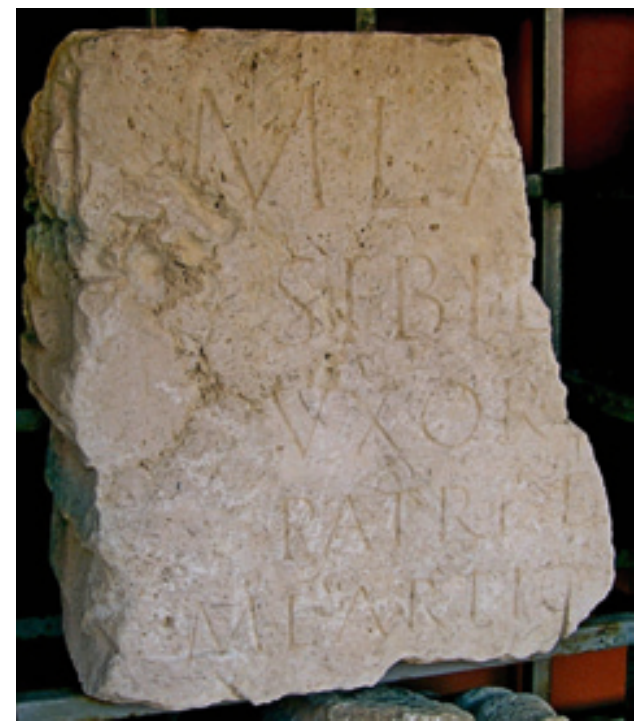

SLIKA 10. Pogled na pročelje elementa trabeacije s natpisom obitelji Lartius (foto: autori)

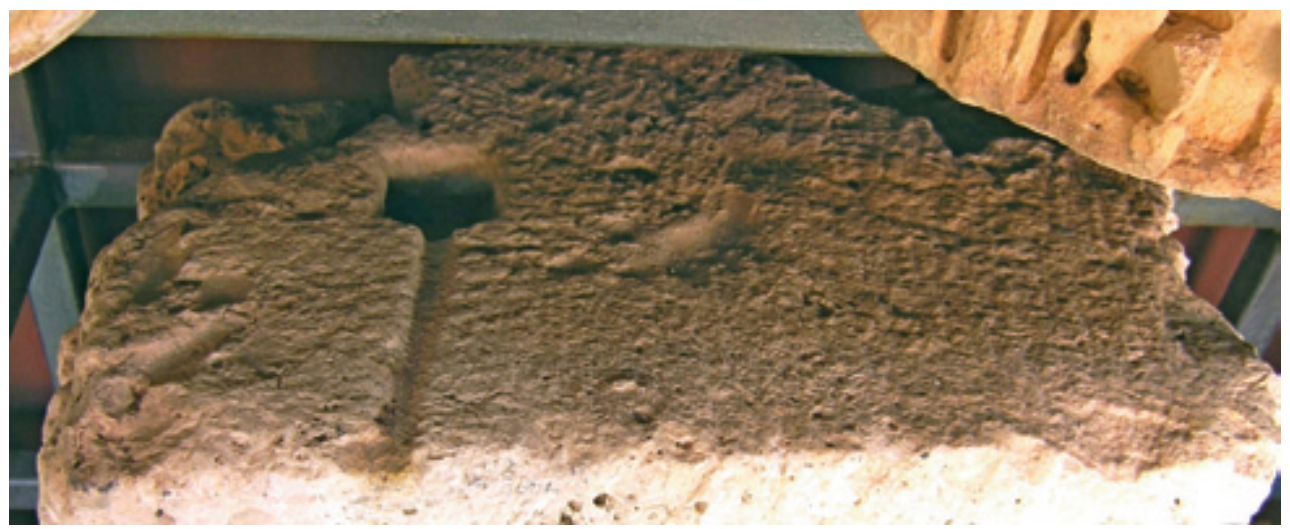

SLIKA 11. Pogled na detalj gornje plohe elementa trabeacije $s$ utorom i kanalom za olovo (foto: autori)

na koju je položen pa je utor danas teško napipati i prepoznati, no prisutnost mu je neupitna. U izvornom stanju sačuvani su gornji horizontalni i vrh lijevog vertikalnog ruba stranice s natpisom. Ti dijelovi formiraju gornji lijevi ugao natpisnog polja, sugerirajući da je ono bilo bez uobičajenog ukrasnog okvira i da je danas sačuvano u punoj visini.

Unutar polja nalaze se ostatci natpisa koji u transkripciji glasi (Sl. 9, Sl. 10): 


\author{
M. LA [...] \\ SIBI.E[...] \\ VXORI $[\ldots]$ \\ PATRI.E [...] \\ M . LARTIO . M [...]
}

Natpis je raspoređen u pet redaka i pisan monumentalnom kapitalom čija se visina smanjuje od prvog prema zadnjem retku, od početnih 11 do završnih 5,5 $\mathrm{cm}$. Unutar teksta su interpunkcije koje imaju trokutasti, ali negdje poprimaju gotovo kružni oblik. U čitanju i razumijevanju izvorne strukture natpisa nema nekih značajnijih poteškoća, što nas dovodi do makar približne rekonstrukcije polja i njegovih dimenzija.

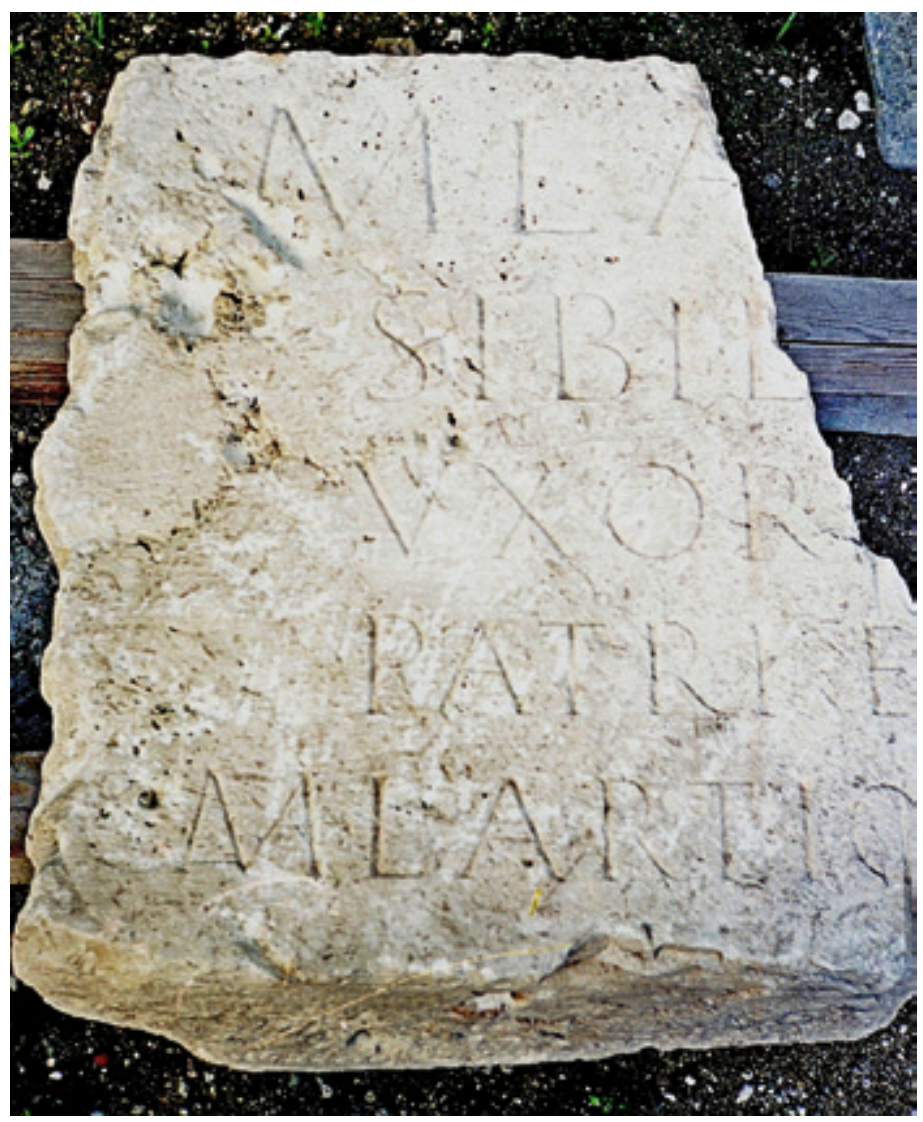

SLIKA 12. Pogled na element trabeacije s vidljivom donjom plohom i utorom za kapitel (Izvor: fototeka AMZd, MNS) 
U natpisu su spomenuta tri muška člana obitelji Lartius: Marko Larcije, čije je ime ispunjalo prvi redak natpisa, njegov otac čije je ime zauzimalo veći dio trećeg retka (iza riječi uxori) i još jedan muškarac s prenomenom Marcus, čije je ime ispunjalo zadnji redak. Pored njih, u natpisu je bila spomenuta i žena prvospomenutoga, čije je ime stajalo u drugom retku (iza veznika et). Sve u svemu, na natpisu su bile spomenute najmanje četiri osobe, tri u dativnom obliku (sukorisnici groba), a samo prva (nalogodavac) u nominativu. Ostaje tek pitanje što je stajalo u nastavku četvrtog retka i treba li u njemu možda vidjeti spomen još jednog člana obitelji.

Za makar djelomičnu restituciju sadržaja natpisa osobito je važan zadnji redak, gdje se prije loma na desnoj strani pojavljuje kosa hasta slova koja je navlas identična prvom slovu u retku $(\mathrm{M})$. Vrlo vjerojatno je riječ o tragu slova $\mathrm{M}$ unutar filijacije $M$ (arci)f(ilius) koja bi aludirala na prvu osobu u natpisu. Druga je mogućnost da je riječ o prvom slovu kognomena. Struktura natpisa upućuje na zaključak da je zadnji muškarac sin prvospomenutoga. Na natpisu su tako bile spomenute tri generacije muških Larcija, pri čemu je posebice važno nasljeđivanje prenomena s oca na sina! Osim toga, važan je i odnos duljine zadnjeg i prvog retka natpisa. Zadnji redak bi bez kognomena bio prekratak, osim ako nije uključivao navod nekih funkcija ili životnu dob pokojnika, a očita je namjera aksijalnog organiziranja sadržaja natpisa. Slijedom svega navedenog, razumna je pretpostavka da je iza nalogodavčeva gentilnog imena (Lartius) u prvom retku slijedila filijacija tada gotovo sigurno $M$ (arci) $f($ ilius). U nastavku je mogao stajati cognomen, a ispred njega možda i navod glasačkog okruga (tribus), čak i u slučaju da kognomena nije bilo. Ime vlasnika grobnice ispunjalo je cijeli prvi redak jer na početku drugoga stoji riječ sibi, koja, osim što objašnjava okolnosti nastanka i familijarne odnose, upućuje na mogućnost da je prvi red završavao natpisnom formulom V F (vivus fecit). Nakon svega elaboriranog ponudili bismo sljedeću restituciju natpisa:

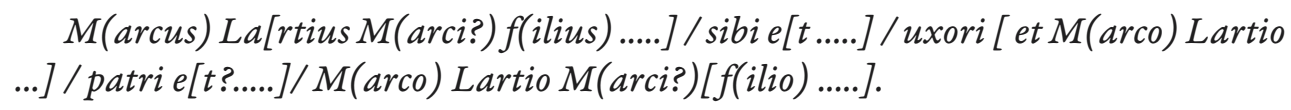

Sada nam valja podsjetiti da je spomenik sačuvan u duljini od $0,57 \mathrm{~m}$, a da je od imena vlasnika sačuvana tek sigla prenomena i prva dva slova gentilicija (Sl. 9 - 10). Prema tome možemo zaključiti da je izvorna duljina prvog retka, a time i natpisa/elementa morala biti višestruko veća od sačuvane. Prema našim procjenama ona je mogla iznositi od minimalno $2 \mathrm{~m}$ do najviše malo preko $3 \mathrm{~m}$. Samo u dijelu koji donosi puni nomen gentile prvog imena element je sigurno dosezao oko $1,5 \mathrm{~m}$, a u nastavku je neupitno prelazio duljinu od $2 \mathrm{~m}$ ! 
Identična „dekoracija“ kao i ona na lijevoj strani tako izduženog bloka (Sl. 9) vrlo vjerojatno se nalazila i na njegovu desnom rubu. Ako je tomu tako, postavlja se pitanje koji sadržaj pripada čeonoj, a koji bočnoj strani spomenika. Držimo da se odgovor nameće sam po sebi - natpis bi pripadao pročelju, a bočne strane bloka lateralnim stranama arhitekture u kojoj je stajao. Time bismo ocrtali izgled pročelja u dijelu trabeacije, a preostala bi složena pitanja izgleda arhitekture na kojoj je element stajao, odnosno izgleda vršnog dijela koji je sjedao na njega.

Izvedba polja s natpisom (u pitanju je obična i to neuokvirena tabula, a ne tabula ansata!) te paleografske i pretpostavljene onomastičke značajke natpisa (kod dvojice muškaraca rimski imenski sustav tipa tria nomina s filijacijom?) upućuju na okvirnu dataciju spomenika. Natpis, a s njime i arhitekturu u kojoj je stajao, svakako treba datirati u rani principat (do oko 160 . po Kr.). ${ }^{45}$ Međutim, svaki je pokušaj preciznije datacije dosta problematičan jer ne raspolažemo s dovoljno podataka (npr. je li prisutnost filijacije sigurna). U ovom slučaju izostanak formule Dis Manibus ne može poslužiti ni kao relativni kronološki reper jer je $M$. Lartius zdanje podigao za života, što se zaključuje po riječi sibi i nedostatku prostora u zadnjem retku da se u njemu eventualno pojavi neko ime u nominativu i prethodno formula TFI ili neka slična. U takvim pak situacijama zazivanje Mana je jako rijetka pojava zbog negativnog prizvuka koji proizvodi. ${ }^{46}$ Drugim riječima, da je natpis kojim slučajem i izrađen u doba početka pune uporabe posvetne formule Manima (sredinom 2. st.), ona bi na njemu mogla izostati. Preko paleografije se pak nezahvalno upuštati u procjenu je li natpis iz 1. st. ili prve polovice i sredine 2. st., kada se filijacija još uvijek zna pojaviti unutar imenovanja rimskih građana. Prisutnost prenomena i pretpostavljena prisutnost filijacije u zadnjem i prvom retku tako su najkonkretniji reperi za datiranje, $s$ gornjom granicom do oko sredine 2. st. ${ }^{47} \mathrm{Užu}$ dataciju od te mogao bi sugerirati jedino materijal od kojega je element izrađen. To je možda isti vapnenac s puno okamina upotrijebljen za ugradbeni reljef s porodicom prikazanom unutar dvije polukružne niše (Sl. 4), što bi bio trag za datiranje u julijevsko-klaudijevsko razdoblje ili barem okvire 1. st. Bez validne petrografske analize to ipak ostaje samo radna hipoteza.

Lartii dosad nisu bili zastupljeni među stanovništvom rimske Enone, što ne treba osobito čuditi jer su obitelji toga imena uopće rijetke na natpisnoj građi

45 Za definiciju ranog principata usporedi: Geza Alföldy, Die Personennamen in der römischen Provinz Dalmatien, Heidelberg, 1969., 19.

46 Usp. npr. zapažanja o pojavi formule na sarkofazima pripravljenima za života vlasnika kod Nenad CAмBI, Sarkofazi lokalne produkcije u rimskoj Dalmaciji, Književni krug, Split, 2010., 35 - 36.

47 Pregledno kod G. Alföldy, Die Personennamen in der römischen Provinz Dalmatien, 27. 
rimske provincije Dalmacije, čak i iz razdoblja kasnog principata. ${ }^{48}$ Ovdje analizirani građevni natpis prva je potvrda imena u gradu i tek treća u Liburniji iz razdoblja ranog principata. Poznata nam je Lartia T(iti) f(ilia) Maxima s natpisa (CIL 3, 3137) iz Raba, a s nadinskog natpisa ILIug 209 još i Sexta Lartia. Po Alföldyju su sve obitelji Larcija podrijetlom iz Italije ili sa zapada, no ime zabilježeno u Nedinu (Nedinum) moglo bi upućivati da ga nosi i domaće stanovništvo. ${ }^{49}$ Velika je šteta što ne raspolažemo informacijom jesu li i enonski Lartii doista nosili kognomene i kako su oni glasili. Zanimljivo je da su ninski Lartii jedina dalmatinska obitelj toga imena čiji pripadnici nose prenomen Marcus. Zbog svega navedenog ne smije se isključiti mogućnost da su enonski Lartii pripadnici triju generacija već romanizirane starosjedilačke obitelji. Prema grobnom mjestu koje je podigao Marko Larcije, obitelj je raspolagala znatnim materijalnim sredstvima i zacijelo uživala veliki ugled u Enoni.

Treći spomenik vezan uz kategoriju monumentalnih grobnih zdanja pripada skupini ugradbenih reljefa, do nedavno pripisivanih dijelovima monumentalnih portretnih stela. ${ }^{50}$ Međutim, recentne studije pokazale su da su ugradbeni reljefi bili inkorporirani $u$ fasade grobnih zdanja, nekada i pravih mauzoleja. ${ }^{51}$ Ti su elementi redovito masivni i monumentalnih dimenzija. Izrađeni su od vapnenačkih blokova pravokutnog oblika koji na prednjici prikazuju polukružno zasvedene niše ili slikovno polje izduženog pravokutnog oblika. Prema nošnji i frizurama pokojnika, prikazanih u statuarnim obrascima togata (muškarci), te palijate i Pudicicije (žene), zapravo gotovo uvijek u njihovoj kombinaciji, može se zaključiti da su vlasnici i korisnici rimski građani iz kruga municipalne elite. Iz tog kruga se potencijalno ne smiju isključiti ni bogati oslobođenici u prvoj generaciji. Do sada su u Enoni potvrđena dva primjerka takvog tipa spomenika (S1. 2 i 4), a ista je pripadnost pretpostavljena za još dva. ${ }^{52}$

Na prostoru Liburnije ugradbeni reljef izuzetno je rijedak tip spomenika, a izvan nje ga u rimskoj Dalmaciji gotovo i nema pa je svaki novi primjerak ili nova

48 Analizu sastava stanovništva municipija Enona prema natpisnoj građi vidi kod M. Dubolnić Glavan, Civitas Aenona, primjer romanizacije liburnske općine, I, 211 - 268.

49 G. Alföldy, Die Personennamen in der römischen Provinz Dalmatien, 92, 296 - 297, s.v. Lartius. Bazi koju je prikupio Alföldy treba pridodati natpis ILIug 209; O tome vidi kod M. Dubolnić Glavan, Civitas Aenona, primjer romanizacije liburnske općine, I, 230.

so M. SuIĆ, Nin u antici, T. XXII/1; M. SuIĆ, Antički Nin (Aenona) i njegovi spomenici, 1969., 97; Mate SuIć, Nin u antici, Nin - povijesni i umjetnički spomenici (ur. Š. Batović, M. Suić, J. Belošević), Zadar, 1986., 59.

51 Pregledno: D. Maršić, Ugradbeni i gradevni portretni reljefi u Histriji i Dalmaciji, 15 i d.; N. CAMBI, Pregled razvoja nadgrobnih spomenika u rimskoj Dalmaciji, 2013., 24 i d.

52 Za sigurne primjerke usp. bilj. 34 i 35. Upitna atribucija: D. MARŠIĆ, Ugradbeni i građevni portretni reljefi u Histriji i Dalmaciji, 33, 88 i d., Kat. C1, C2, T. 12/1-2. 


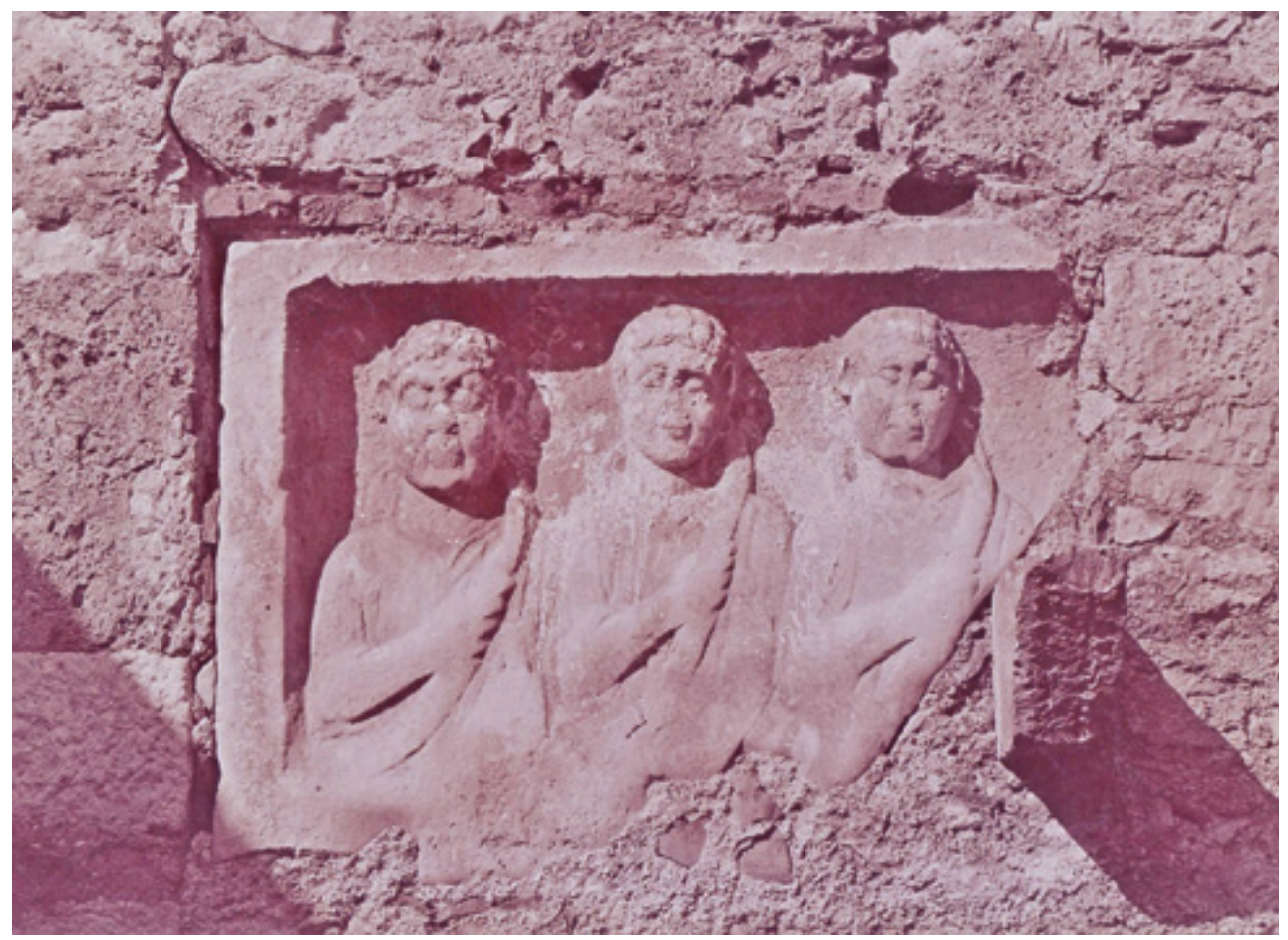

SLIKA 13. Ugradbeni reljef uzidan u kući Tartaro u Ninu početkom 20. st. (foto: L. Jelić; Izvor: AMS, Arhiva L. Jelića, preuzeto iz: M. Dubolnić Glavan, Civitas Aenona, 2015., 100, Sl. 49)

spoznaja o postojećima više nego dragocjena. Pripadnost skupini ugradbenih reljefa pretpostavljena je i za reljef s portretom mlađeg togata oštećenih partija lica uzidan u kuću Tartaro u Ninu. Do prije nekog vremena spomenik je bio vidljiv u cijelosti, iako debelo ožbukanih rubova (Sl. 14), no danas je nažalost zakriven ugradnjom drvenih vrata (Sl. 15). Prema usmenoj predaji reljef je nekoć prikazivao tri muška lika, a na jednofiguralni format sveden je nakon požara. ${ }^{53}$

Više podataka o tome dobiveno je pregledom Arhive dr. L. Jelića. Među bogatom građom nastalom prilikom istraživanja Nina početkom 20. st. pronađena je fotografija reljefa dok je bio u cijelosti vidljiv (Sl. 13). ${ }^{54}$

$\mathrm{Na}$ Jelićevoj fotografiji vide se tri muška portreta u blago produljenom polufiguralnom isječku (do malo ispod struka), potpuno istog držanja i nošnje, ali različite visine i veličine glave. Donju nošnju čini tunica, koja zbog širokog romanizacije liburnske općine, I, 100 - 101, S1. 49. 


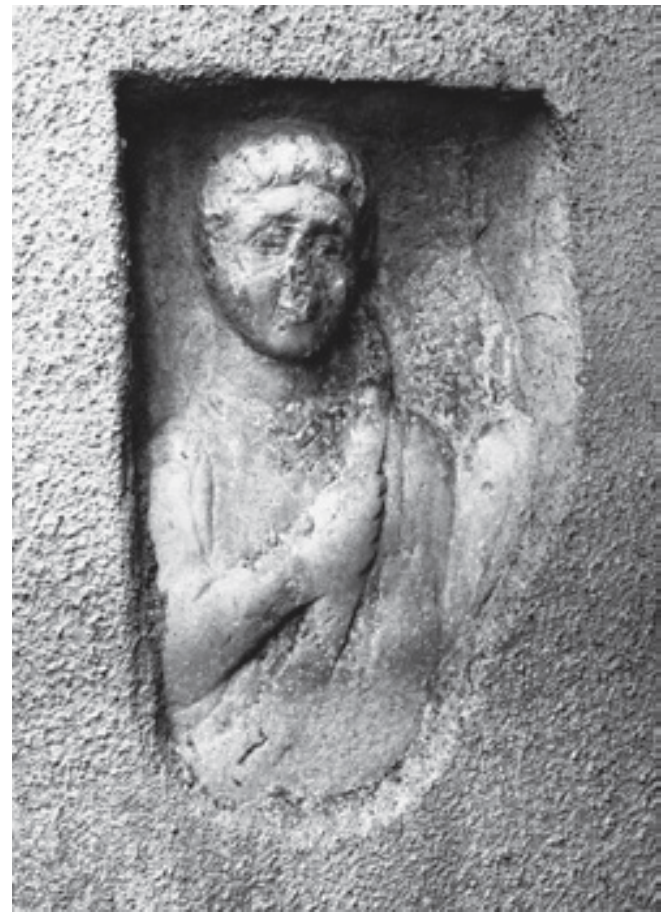

SLIKA 14. Fragment ugradbenog reljefa u kući Tartaro 2002. godine (foto: D. Maršić)

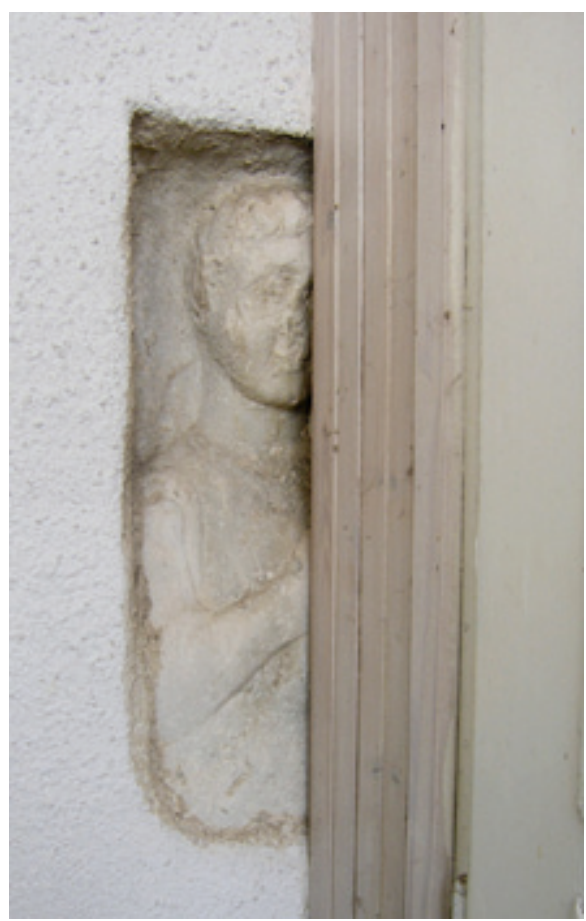

SLIKA 15. Fragment ugradbenog reljefa u kući Tartaro 2019. godine (foto: D. Maršić)

kroja formira rukave, gornju toga s napetim i naboranim umbom, a taj dio ogrtača i balteus šakom hvata izložena desna ruka. ${ }^{55}$ Krajnji lijevi lik (gledano prema reljefu) je najniži, ali i najkrupnije glave, dok su ostala dva približno iste visine, ali bez sumnje različite dobi i možda malo nagnutih glava u svoju lijevu stranu. Lik u sredini je najmlađi i upravo je on taj koji je i danas vidljiv. To jasno pokazuje usporedba glava, izlizano desno uho i duboka brazda na balteusu toge (usporedi Sl. 13 - 15). Iz toga se može zaključiti da je reljef „skraćen“ na način da su ostala dva lika u cijelosti odlomljena ili zbog oštećenja ožbukana, a dio ramena koji se danas vidi pripada nekada desnom liku (Sl. 15).

55 O terminu, funkciji i pojavi umba vidi u: Hans Rupprecht Goette, Studien zu romischen Togadarstellungen, Mainz am Rhein, 1990., 3 - 29 i d., T. 94. Navedeni tip toge autor označava kraticom Ca i njegovu pojavu datira u ranije flavijevsko doba vidi 54 i d., T. 15 i d; O istom tipu usporedi i Srđana SchönAuer, Odjeća, obuća i nakit u antičkoj Dalmaciji na spomenicima iz Arheološkog muzeja u Splitu, Vjesnik za arheologiju i historiju dalmatinsku, 93, Split, 2001., 399, S1. 24. 
Sva tri muškarca prikazana su pomalo gojaznih obraza i stisnutih usta, a desna dva čini se i istih frizura, što se $s$ fotografije ipak ne može smatrati pouzdanim. Nalaze se u poprečno izduženoj pravokutnoj niši čije su tri stranice obrubljene uskim ravnim okvirom. Već sama izvedba okvira jasno pokazuje da ne može biti posrijedi stela, a to dodatno osnažuje i poprečna koncepcija spomenika. Desna strana reljefa je u visini glava najprije odrezana otprilike okomito, a u nastavku prema donjem rubu dijagonalno. Na njihovu spoju jasno se uočava draperija ogrtača oko vrata još jednoga, danas izgubljenog lika. Prema svemu navedenom, reljef pripada varijanti s poprečno koncipiranim pravokutnim slikovnim poljem i izvorno je prikazivao najmanje četiri portreta pokojnika, a upravo je višefiguralnost jedna od prepoznatljivih odlika ugradbenih reljefa. ${ }^{56}$ Međutim, ne može se isključiti mogućnost da je bio i duži! S obzirom na to da su sva tri sačuvana lika muška, i to različite dobi, a da je ugradbeni reljef spomenik koji je po prirodi stvari obiteljskog karaktera, lako je moguće da mali trag draperije pripada ženskom portretu. No ako je ipak riječ o još jednom muškom portretu, ženski bi možda trebalo tražiti do njega, na nekoć krajnjoj desnoj strani reljefa. Nažalost, ostatci reljefa nisu dostatni za sigurno zaključivanje. Na ovom mjestu možemo se tek pozvati na druge ugradbene reljefe na kojima se gotovo uvijek pojavljuje bračni par (npr. ovdje Sl. 2 i 4), kao i na prethodni natpis Larcija, gdje je uz muškarce spomenuta i žena vlasnika. Uzevši te podatke u obzir, mišljenja smo da je krajnji desni lik na Jelićevoj fotografiji vlasnik grobnice kraj kojega je mogla stajati supruga, da je mlađi (sačuvani) lik njegov sin, a krajnji lijevi mogao bi mu biti otac.

Da je reljef proizvod domaćih klesarskih radionica nema potrebe posebno obrazlagati; jasno to pokazuje materijal, ali i stilska pojedinost u izvedbi okrajka toge oko vrata (koji neprirodno visi u zraku), koja se pojavljuje na više enonskih nadgrobnih spomenika iz 1 . st. po $\mathrm{Kr}^{57}$ Spomenici julijevsko-klaudijevskog razdoblja znatno su kvalitetnije klesani te na njima spomenuti detalj uglavnom izostaje (vidi ovdje Sl. 2, 4 i 16). Može se pretpostaviti da je to likovno obilježje kasnije klesarske produkcije, kada dolazi do znatnog pojednostavljivanja, okrupnjivanja i ogrubljivanja formi. Naravno da se takva razlika može pripisati i djelatnosti dviju radionica, no držimo da je u ovom slučaju riječ i o kronološkoj distinkciji. Ni frizura sačuvanog lika mladića ne dopušta datiranje ranije od 40-ih ili 50-ih godina 1. st., ali ni kasnije od 90-ih godina istog stoljeća. Na njoj je naime prisutna moda češljanja kose u slojevima, tj. u dugim i stubasto

56 Za tipologiju usp. D. Maršıć, Ugradbeni i gradevni portretni reljefi u Histriji i Dalmaciji, 60.

57 Usp. npr. bilj 52 (C2). 
oblikovanim pramenovima (gradus). Takva moda afirmira se na portretima Klaudija i Nerona, ali se kao neka vrsta neronovske tradicije nastavlja na portretima Tita i Domicijana, posebice zadnjega među Flavijevcima. ${ }^{58} \mathrm{Na}$ spomeniku iz Nina taj je gradus naravno uvelike stiliziran pa djeluje kapoliko, ali se bez problema uočava višeslojnost. Debljinom pramenova i dubokim kanalima željelo se oslikati njihov volumen i duljinu, a krajevima iznad čela srpolike ili kukičaste uvojke kojima su gradus frizure završavale. Konkretno se uočavaju dva reda uvojaka. Oni koji padaju na čelo su kraći i vrhova okrenutih nadesno od sredine čela (gledano iz mjera glave). Smjer uvojaka iznad lijevog oka nije posve siguran, ali barem oni u uglu čela padaju prema lijevom uhu. Takav smjer i raspored uvojaka čini se sugeriraju da uzor nisu bili direktno Neronovi portreti zadnja dva tipa, ni dva tipa Titovih portreta. Uzor najvjerojatnije treba tražiti u jednom od prva dva portretna tipa Domicijana, i to u jednoj slobodnijoj verziji. ${ }^{59}$

Mladićev portret može se i u oblikovno-stilskom pogledu usporediti s nekim Domicijanovim glavama, npr. onom iz Pergama na kojoj je snažno izražen patos, iako nosi ponešto drugačiji raspored pramenova iznad čela. ${ }^{60}$ I na glavi mladića može se raspoznati taj odmak od klasicističke smirenosti i pokušaj iskazivanja patetike torzijom u lijevu donju stranu. Usporedbe se mogu naći i među nekim privatnim ranoflavijevskim portretima, na kojima je neronovska modna tradicija još uvijek jaka, kao npr. na bisti Gaja Vibija Severa iz Metropolitan Museum of Arts. ${ }^{61}$

Desni, žbukom prekriveni muškarac vjerojatno je slijedio isti ili sličan način češljanja, dok je lijevi mogao imitirati Vespazijana. Čini se da je njemu središnji

58 Frizura mladića u principu je istoga tipa kao i one koje nose T. Fuficije i njegov oslobođenik Privat na znamenitoj steli iz Salone. Za njih usporedi Nenad CAMBI, Imago animi - antički portret u Hrvatskoj, Split, 2000., 44 i d., T. 62. Ima i drugih usporedivih primjera.

59 O karakteristikama 3. i 4. tipa Neronovih portreta usporedi Dražen MARŠić, Izgubljeni salonitanski spomenici (II). Portretne stele vojnika VII. legije C.p.f. Gaja Lukrecija i Lucija Cezija Basa, Vjesnik $z a$ arheologiju i povijest dalmatinsku, 103, Split, 2010., 71 i d., Sl. $6-7$, gdje se donosi i druga referentna literatura. Za dva tipa Titovih portreta vidi: Dražen MARšıć, Fragment Vespazijanove glave iz Arheološkog muzeja Zadar, Diadora (Batovićev zbornik), 26 - 27, Zadar, 2014., 493 i d., Sl. 12 - 13; O tipologiji i karakteristikama Domicijanovih portreta: Marianne Bergmann, Paul ZAN KER, Damnatio memoriae - Umgearbeitete Nero - und Domitiansporträts. Zur Ikonographie der Flavischen Kaiser und des Nerva, Jahrbuch des Deutchen Archäologischen Instituts, 96, 1981., 366 i d., sl. 38 i d.

60 Georg Daltrop, Ulrich Hausmann, Max Wegner, Die Flavier. Vespasian, Titus, Domitian, Nerva, Iulia Titi, Domitilla, Domitia, Das rőmische Herrscherbild, II/1, Berlin, 1966., 38, T. 33a-b. Ovisno o tome pod kojim je kutom snimljena, pergamska glava nekim detaljima jako podsjeća na mladića iz Enone.

${ }^{61}$ Ilustracija Globulove stele: https://www.alamy.com/stock-photo-marble-funerary-stele-of-gaiusvibius-severus-roman-early-flavian-81337345.html (pristup ostvaren 13. 2. 2019.). 
i desni dio glave bio odlomljen jer se lijevi dio neprirodno izdiže i samo su na njemu vidljivi snažni pramenovi (Sl. 13). Taj detalj ipak ostaje nepoznanica jer se samo temeljem priložene fotografije o njemu ne može sa sigurnošću raspravljati. Na temelju modnih i stilskih karakteristika reljef se može datirati u period od kraja 60-ih do 90-ih godina 1. st. Takva datacija je u čvrstom suglasju i sa stilom drapiranja toge, koji zbog izostanka umba „U“ oblika a priori govori protiv ranijeg postanka. ${ }^{62}$

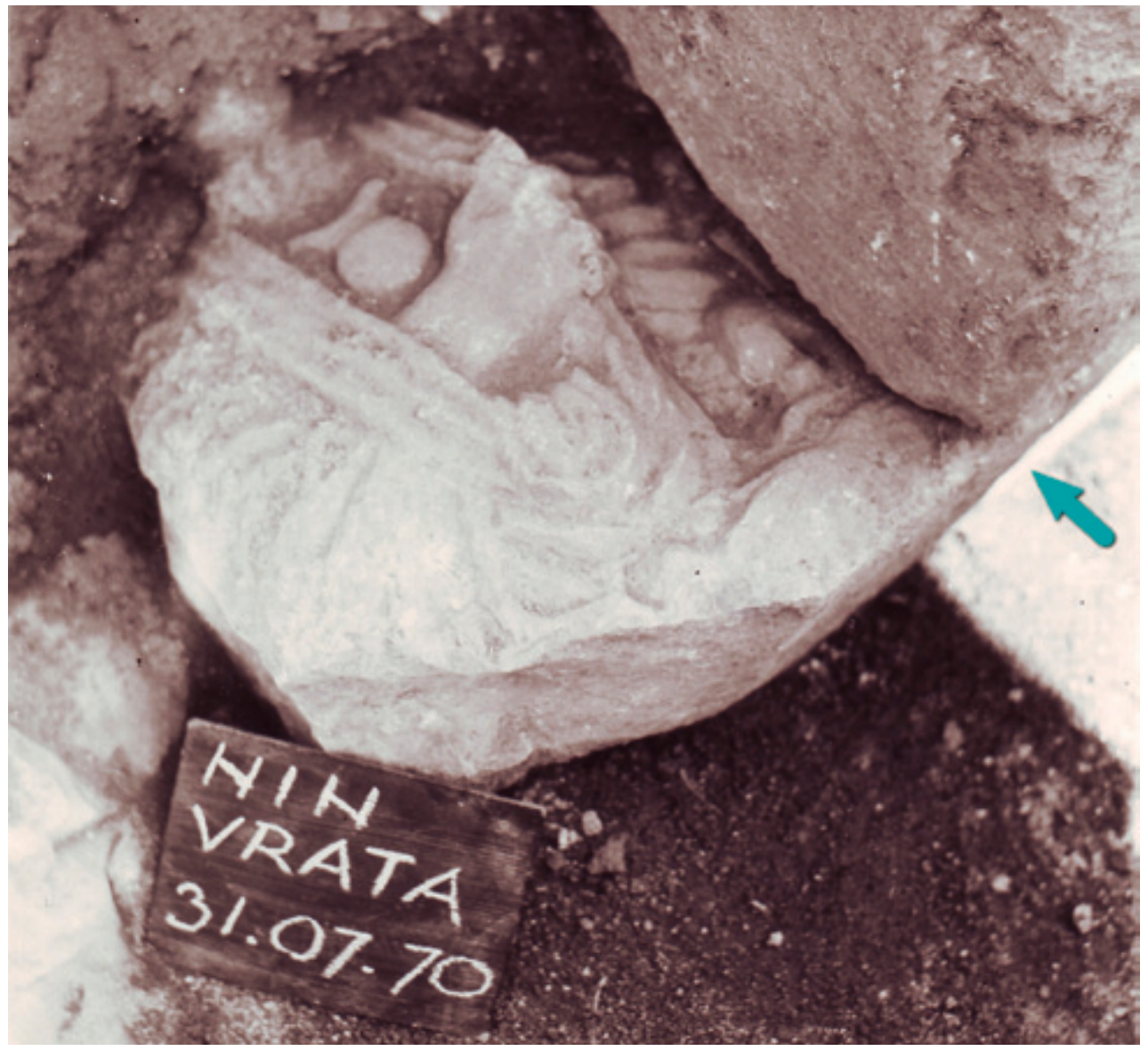

SLIKA 16. Pogled na fragment nadgrobnog reljefa pronađenog na položaju Dvorine u Ninu (Izvor: fototeka AMZd, preuzeto iz: B. Ilakovac, Izvještaj o sondažnim radovima u Ninu 1970. (Prahulje - Dvorine), 1970., 174, Sl. 7)

62 Usporedi bilj. 55: H. R. Goette, Studien zu romischen Togadarstellungen, 3 - 29, T. 94; S. SCHÖNAUER, Odjeća, obuća i nakit u antičkoj Dalmaciji na spomenicima iz Arheološkog muzeja u Splitu, 399, Sl. 24. 
Godine 1970. na položaju Dvorine u Ninu, istom onom s kojeg potječe i blok $s$ natpisom Larcija, kao spolij u kasnoantičkom zidu (možda obrambene kule uz vrata) otkriven je fragment ranocarskog nadgrobnog spomenika. O spomeniku nikada nije napisana rasprava ili opsežniji komentar jer je nakon završetka istraživanja izgleda ostavljen u strukturi u kojoj je stajao. Objavljeni su samo šturi podatci - tek nekoliko riječi i fotografija voditelja istraživanja B. Ilakovca (Sl. 16). ${ }^{63}$ Iako je fotografija osrednje kvalitete i načinjena pod lošim kutom, bitne ikonografske pojedinosti u cijelosti se razabiru.

Na spomeniku je uočljiv lik zakopane glave u formatu polufigure. Nesumnjivo je riječ o togatu dječačke dobi jer mu oko vrata visi bulla - medaljon obješen na ogrlici i spušten na grudi, zapravo neka vrsta ampule u kojoj su čuvani amuleti. Bulla je nakit karakterističan ponajprije za rimske dječake i simbol je njihova slobodnog rođenja i roditeljske nade budućeg društvenog prosperiteta. Dobivali su je kod rođenja s namjerom da odagna zle sile, uroke i bolesti i nosili sve do oblačenja toge za odrasle u 16. ili 17. godini života (toga virilis), tj. neke vrste punoljetnosti. ${ }^{64}$ To pak znači da toga na ninskom spomeniku može biti samo ona toga koja je nošena prije "prijelaza“, odnosno toga praetexta. ${ }^{65}$ Toga je prikazana na način da je kao u zavoju obgrlila desno rame i u luku se (balteus) penje na lijevo rame. Iz „luka“ proviruje zapešće desne ruke čiji prsti pridržavaju skut ogrtača. Ispod ruke izviruje mali umbo u obliku slova „U“. Mora se spomenuti da opisano drapiranje djeluje pomalo neobično i nezgrapno, a to odatle što ranocarski tip toge s umbom (koji se kao modni element pojavljuje od Augustova doba) gotovo u pravilu ostavlja desno rame slobodnim, dok je ovdje pokriveno. ${ }^{66}$

63 Boris Ilakovac, Izvještaj o sondažnim radovima u Ninu 1970 (Prahulje - Dvorine), Diadora, 5, Zadar, 1970., 174, Sl. 7; O spomeniku vidi još kod M. Dubolnić Glavan, Civitas Aenona, primjer romanizacije liburnske općine, I, 259 - 260, Sl. 93.

64 Sažeto o buli: Larissa Bonfante Warren, Roman Costumes - A Glossary and Some Etruscan Derivations, Aufstieg und Niedergang der römischen Welt, I/4, Berlin - New York, 1973., 605, s.v. bulla; H. R. Goette, Studien zu romischen Togadarstellungen, 104 (Anhang I: Die Bulla). O kontroverzi jesu li bulu kod rođenja dobivale i djevojčice usp. Judith Lynn Sebesta, Symbolism in the Costume of the Roman Woman, The World of Roman Costume (ed. J. Lynn Sebesta - L. Bonfante), The University of Wisconsin Press, 2001., 47, bilj. 14, gdje se donosi i relevantna literatura.

65 Sažeto: L. Bonfante Warren, Roman Costumes - A Glossary and Some Etruscan Derivations, 611 , s. v. praetexta. O preteksti kao „nošnji iščekivanja”, tj. istoj simbolici nade roditelja da će njihov sin jednom obnašati (ili da je trebao obnašati) najviše službe, s izvadcima iz rimskih pisanih vrela: H. R. GoetT E, Studien zu romischen Togadarstellungen, 4-15, Q51-67. Pregledno u našoj literaturi: S. SchöNAUER, Odjeća, obuća i nakit u antičkoj Dalmaciji na spomenicima iz Arheološkog muzeja u Splitu, $400-401,422$.

66 Usp. H. R. Goette, Studien zu romischen Togadarstellungen, 29 i d., T. 5 i d; Usporedi i S. SCHÖNAUER, Odjeća, obuća i nakit u antičkoj Dalmaciji na spomenicima iz Arheološkog muzeja u Splitu, 399, Sl. 22. 
Neki slični prikaz na tlu rimske provincije Dalmacije nije nam poznat, dok je na italskom tlu takva ikonografija razmjerno česta pojava. ${ }^{67}$ Lijevi dio dječakova tijela vidi se lošije jer je pokriven blokom ispod kojeg je reljef stajao. Draperija toge pokriva lijevu nadlakticu i prebačena je na njezinu vanjsku stranu. Da ne mogu biti posrijedi spiralni kaneliri tordiranog stupića pokazuje to što nabori nisu istog smjera i širine. Podlaktica je čini se bila gurnuta naprijed i ispružene šake položene uz tijelo, ispod umba toge, jer se iz bezlične mase kamena izdvaja dio reljefa koji se može prepoznati kao palac. Između "palca“ i nadlaktice kao da se nazire nekoliko manjih rozetica svrdlanih središta, no možda je riječ o dojmu koji uopće ne odgovara zbilji. Odmah pored njih pojavljuje se izdignuti dio reljefa zagonetnog karaktera.

Reljef je bez osobnog pregleda nemoguće tipološki odrediti, a podjednaka je mogućnost njegove pripadnosti monumentalnoj portretnoj steli i ugradbenom reljefu. Da ne može biti riječ o dijelu kipa vidljivo je po ravnoj donjoj stranici koja se nekoliko desetaka centimetara uvlači ispod bloka koji nadvisuje reljef (usp. strjelicu na S1. 16). To je utoliko interesantno što je bulla do sada bila poznata samo na kipovima, a ne i na portretnim stelama i ugradbenim reljefima istočne obale Jadrana. ${ }^{68}$ Samo preko fotografije teško je procijeniti je li donja ravna stranica fragmenta izvoran ili sekundaran detalj izrade spomenika. Pravilnost bi prije upućivala na izvornost elementa, negoli na preradu, što bi mogao biti glavni putokaz u prepoznavanju tipološke pripadnosti spomenika.

B. Ilakovac spomenik interpretira kao "fragment rimske stele“ ${ }^{69}$ No kako istodobno tvrdi da je prikazani lik odjeven u hiton, $u$ tu se procjenu ne možemo pouzdati. Sedamdesetih godina 20. st. nije bila poznata prisutnost ugradbenih reljefa na istočnom Jadranu, niti ih je većina autora bila u stanju razlikovati

67 Usp. npr. Gemma ChiesA, Una classe di rilievi funerari romani a ritratti dell'Italia settentrionale, Studi in onore di A. Calderini e R. Paribeni, III, Milano - Varese, 1956., 392 i d., br. i Sl. 5 i 6 (reljefi iz Akvileje). U oba slučaja prikazani su stariji muškarci kraj svojih supruga (palijata veliranih glava), držanja identičnog onome koje smo i ovdje pretpostavili za dječaka (u lijevim su im rukama plodovi). Figure se nalaze unutar jednostavnog ravnog okvira, a autorica ih datira u prvu polovinu 1. st. po Kr.

68 Dva razmjerno poznata kipa togata-dječaka s bulom su npr. akefalni kip iz salonitanskog mauzoleja obitelji Lollius, danas izložen u lapidariju Arheološkog muzeja u Splitu, i salonitanski akefalni kip s utorom za glavu pohranjen u Arheološkom muzeju u Zagrebu. Za prvi kip usporedi Dražen MARŠIĆ, Augustovo doba i početci provincijalne nadgrobne umjetnosti u Dalmaciji, The Century of the Brave. Roman Conquest and Indigenous Resistance in Illyricum during the time of Augustus and his heirs / Stoljeće hrabrih. Rimsko osvajanje i otpora starosjedilaca u Iliriku za vrijeme Augusta i njegovih nasljednika, Proceedings of the International Conference, Zagreb 22. - 26. 9. 2014. (ur. M. Milićević Bradač, D. Demicheli), Zagreb, 2018., 202 i d., S1. 15; Za drugi kip vidi u: Ana Sedlar Torlak, Zbirka Vicka Solitra u Arheološkom muzeju u Zagrebu, Tusculum, 7, Solin, 2014., 194, S1. 4.

69 B. Il A Kovac, Izvještaj o sondažnim radovima u Ninu 1970 (Prahulje - Dvorine), 174, Sl. 7. 
od stela. Interesantno je da se dječaci-togati s bulom na reljefnim nadgrobnim spomenicima pojavljuju gotovo uvijek s roditeljima jer prikaz nosi simboliku obiteljskog zajedništva ili opraštanja. ${ }^{70}$ A ko su između dječakove lijeve nadlaktice i tijela doista prikazani cvjetovi, gotovo je sigurno da je na toj strani bila prikazana njegova majka, dok bi na suprotnoj valjalo tražiti oca. Ovisno o veličini obitelji, portreta je moglo biti i više. Ako tomu i nije tako, istaknuti dio reljefa u visini umba nejasne pripadnosti svakako je još jedan signal da se reljef pružao i ispod susjednog kamenog bloka. Možda taj dio treba vidjeti kao prednje noge nekog kućnog ljubimca? Pridodamo li tomu činjenicu da je vidljivi okomiti rub reljefa nepravilno odrezan te da nema okvira koji prati dječakov lik s vanjske strane, dobivamo prilično pouzdane pokazatelje da je reljef i na toj strani bio manjkav te konture nekadašnje poprečne koncepcije. Uz ravnu donju stranicu to bi sve mogli biti odlučujući razlozi svrstavanja u skupinu ugradbenih reljefa! U ovom trenutku priklanjamo se takvoj interpretaciji i zbog toga smo reljef i uvrstili u rad o monumentalnim grobnim zdanjima. Radi nepostojanja donjeg okvira reljef se može usporediti s ugradbenim reljefom integralno poznatim s crteža M. Sabljara (Sl. 2) te s reljefom koji prikazuje obitelj u dvije niše (S1. 4). To bi pak mogao biti znak njihova bliskog ili zajedničkog radioničkog podrijetla pa odatle vjerojatno i vremena izrade koje ne bi prelazilo okvire julijevsko-klaudijevskog razdoblja. Ne možemo ne konstatirati da je velika šteta što fragment nije do kraja otkriven i izvađen jer u njegovu slučaju konzervatorski pristup nije smio prevladati!

\section{TIPOLOGIJA GROBNIH ZDANJA}

Prethodno donijeti arhitektonski ostatci i preživjeli segmenti skulpturalne dekoracije ukazuju na nadzemna zdanja pravokutnog ili kvadratnog tlocrta, koja se međutim ne smiju smatrati homogenom skupinom.

Zahvaljujući fotodokumentaciji, poznata je tlocrtna osnova jedne takve građevine istražene na položaju Kulina u Vrsima. Građevina je pouzdano bila longitudinalnog tipa i pravokutnog oblika (S1. 5). To je i jedino zdanje za koje možemo pretpostaviti da je izgrađeno kao kompaktna i samostojeća građevina jer se zbog lokacije i pojave prilaznog područja ne može okarakterizirati

70 Usporedi npr. Paul ZANker, Grabreliefs römischer Freigelassener, Jahrbuch des Deutchen archäologischen Instituts, 90, Berlin, 1975., 290 i d., Sl. 19, 25, 26. Na prvom reljefu dječak s bulom nalazi se pilastrom odvojen od roditelja, a na ostala dva je prikazan između njih. Prvi prikazuje tri (zdesna je odlomljen), a ostali četiri lika. Svi dječaci su ingenui, a njihovi roditelji libertini. I na drugim se sličnim reljefima djeca (nekad naga) prikazuju između roditelja. Prikazi djevojčica $s$ bulom nisu poznati. 
kao otvoreni grobni areal. Mogućnost da je prilaz služio kao protiron (sa stubištem?), njegov odnos prema celi i čini se mjestimična nazočnost izvornog estriha (podnice) na nekoliko mjesta unutar cele, pokazuju da je građevina najvjerojatnije imala izgled kuće (njem. Grabhaus, engl. house-tomb). ${ }^{71} \mathrm{Zbog}$ tih je razloga i dovedena u vezu sa sličnom građevinom iz Mulina, od koje bi trebala biti nešto starija. Grobnice toga tipa osobito su bile popularne tijekom 2. i 3. st., o čemu svjedoče razmjerno brojni i dobro proučeni arhitektonski ostatci, npr. oni u Vatikanu ispod Sv. Petra, na umjetnom otoku Isola Sacra između Ostije i Porta i drugdje. ${ }^{72}$ U Rimu su „kućne grobnice“ najčešće građene od cigle ili u tehnici opus reticulatum. Sastoje se od podzemnih odaja i često su podignute na dva kata iznad zemlje, ali ima i jednostavnih prizemnih struktura, što je na Isoli Sacri osobito česta pojava. Na obje je nekropole dobro dokumentirano da građevine iz 2. st. imaju zidove raščlanjene brojnim nišama. Kod građevina iz 3. st. (severskog doba) ta prepoznatljiva karakteristika počinje izostajati, dok su bačvasti svodovi sveprisutna pojava. Još je jedna zanimljiva pojava da se od 2. i u 3. st. grobnicama (često naknadno) prigrađuju nenatkrivena i za ukope često namijenjena predvorja ili pak nove grobnice s krovom. Grobnice iz Vrsi i Mulina građene su od kamena i nemaju neke od spomenutih značajki. Ipak je posve jasno da pripadaju jednoj od razvojnih grana opisanog tipa, koji je u lokalnoj sredini našao vlastiti, resursima primjereni arhitektonski izraz.

Već smo spomenuli da je mauzolej u Mulinama M. Suić rekonstruirao $s$ bačvastim svodom i krovom na dvije vode, našavši uporište u lateralnim zidovima veće debljine u odnosu na ostala dva. No u slučaju mauzoleja iz Vrsi nema podataka na koje bi se po tom pitanju moglo osloniti. Š. Batović u izvještaju ne spominje nalaze koji bi upućivali na prisutnost svoda (npr. sedrene blokove), dok s druge strane spominje „dijelove stropova“ (ne i njihov

71 Treba upozoriti da terminologija nije usuglašena i da se za iste tipove koriste brojni i veoma različiti nazivi. Za tipologiju grobnica, njihove karakteristike i terminologiju, od brojne literature usporedi npr. Jocelyn Mary Catherine Toynbee, Death and Burial in the Roman World, Baltimor and London, 1996., 101 i d.; Henner von Hesberg, Römische Grabbauten, Darmstadt, 1992., 55 i d., S1. 15 i d.; Gabrielle Kremer, Antike Grabbauten in Noricum. Katalog und Auswertung von Werkstücken als Beitrag zur Rekonstruktion und Typologie, Wien, 2001., 23 i d., 57 i d., 317 i d. Pregledno o grobnicama tipa kuće: J. M. C. ToynbeE, Death and Burial in the Roman World, $132 \mathrm{i} \mathrm{d.}$

72 Sv. Petar u Vatikanu: J. M. C. Toynbee, Death and Burial in the Roman World, 87 i d., Fig. 4, 138 i d., Pl. 45 - 48; Isola Sacra 82 i d., Fig. 3, 134 i d., Pl. 43 - 44; H. von Hesberg, Planung und Ausgestaltung der Nekropolen Roms im 2. Jh. n. Chr., Römische Gräberstraßen, Selbstdarstellung Status - Standard, Kolloquium in München vom 28. bis 30. Oktober 1985 ( ur. H. von Hesberg, P. Zanker), München, 1987., 60 i d., Sl. 2 - 4; Ida BALdAss ARRE, La necropoli dell Isola Sacra (Porto), Römische Gräberstraßen. Selbstdarstellung - Status - Standard, Kolloquium in München vom 28. bis 30. Oktober 1985 (ur. H. von Hesberg, P. Zanker), München, 1987., 125 i d., Plan 1, 2. 
materijal), ali iz njegovih riječi proizlazi da isti pripadaju ranijem horizontu. ${ }^{73}$ Iz fotodokumentacije se pak čini kako neke veće razlike u debljini zidova nije bilo. Možemo se samo domišljati jesu li zidovi s unutrašnje strane imali ojačanja na kojima je počivao svod, ali se do njih u istraživanjima nije došlo. Bez obzira na ta i druga otvorena pitanja, bačvasti svod i krov na dvije vode smatramo najprihvatljivijom rekonstrukcijom gornjeg dijela zgrade.

Mauzoleji iz Vrsi i Mulina mogli su imati i posvetni natpis iznad vratnog nadvoja, možda upravo u funkciji nadvratnika. Teško je naime vjerovati da bi takvi objekti mogli funkcionirati bez svečanih natpisa, tim prije što je sarkofag iz Mulina bio jednostavne izrade i možda anepigrafski. U vremenu kada su izgrađeni moda upotrebe tzv. ugradbenih reljefa već je bila davno okončana. U Rimu završava oko druge polovine 2. st., a dulje nije mogla trajati ni u Dalmaciji, pa odatle ne postoji ni teoretska mogućnost njihove pojave. ${ }^{74}$ Protiv toga govori i prisutnost predvorja, koje je moglo imati vlastiti krov visoko naslonjen na pročelje.

I blok s natpisom obitelji Lartius pripadao je zdanju pravokutnog ili kvadratnog tlocrta, na što upućuje izvedba sačuvanog lijevog ugla sa stranicama pod kutom od $90^{\circ}$ (Sl. 9). Pojava arhitrava i friza, tipičnih za hramsku arhitekturu, i dvaju tipova utora za sidrenje na gornjoj i donjoj plohi navode na razumnu pretpostavku da je element stajao na određenoj visini. Sigurno je nosio nekakvo nadgrađe i stajao na stupovima visine srazmjerne njegovoj visini. Sve navedeno upućivalo bi na tip hramskog groba, u najširem smislu te riječi. ${ }^{75}$ Ključni je detalj utor na donjoj plohi $16,5 \mathrm{~cm}$ udaljen od lijevog ugla i $8 \mathrm{~cm}$ od prednje strane, koji nedvojbeno dokazuje da je element počivao na stupovima, odnosno njihovim kapitelima. Da je element stajao unutar zidane blokovske strukture, utor ne bi bio potreban.

Veličinu kapitela moguće je približno izračunati i tako dobiti aproksimativnu visinu pročelja do vrha trabeacije (vijenca). Udaljenost utora od lijevog ruba treba pomnožiti s dva (16,5 x 2) i svakoj strani dodati još oko $5-10 \mathrm{~cm}$, za koliko je kapitel abakom sigurno izlazio ispred trabeacije. ${ }^{76}$ Tom računicom dobiva se širina kapitela pri vrhu od oko $0,50 \mathrm{~m}$. Približno je isti rezultat i kad se na zamišljeni

73 Š. BAtović, Rad Arheološkog muzeja u Zadru od 1970. do 1972., 280.

74 Usp. D. MARšIć, Ugradbeni i gradevni portretni reljefi u Histriji i Dalmaciji, 13 i d. (Italija), 57 i d. (istočni Jadran).

75 O hramskim grobnicama pregledno: J. M. C. Toynbee, Death and Burial in the Roman World, 130 i d., Pl. 37.

76 Odličan crtež spoja ugaonog stupa i trabeacije može se vidjeti u studiji G. Kramer, Antike Grabbauten in Noricum. Katalog und Auswertung von Werkstücken als Beitrag zur Rekonstruktion und Typologie, 15, Sl. 2. 
kapitel pozicionira dubina bloka trabeacije koja, podsjetimo, iznosi $0,32 \mathrm{~m}$ ! Ti se izračuni poklapaju s onim izvedenim osloncem na Vitruvijeve modele ili na neke odlično dokumentirane primjere hramske arhitekture, kao npr. na kapitolijski hram u Zadru. ${ }^{77}$ Zanimljivo je da je element s natpisom Larcija točno dvostruko niži od trabeacije hrama u Zadru (inače dvodijelne izrade). Na prvi se pogled čini da i većinu drugih pripadajućih elemenata grobnice možemo aproksimativno dobiti prepolovivši dimenzije zadarskih. ${ }^{78}$ No to bi nas odvelo u pogrešku. Zadarski su kapiteli pri vrhu širine 1,23 m ili točno koliko je visoka trabeacija, što bi značilo da bi širinu naših kapitela trebalo projicirati na oko $0,60 \mathrm{~m}$, a to je ipak previše. Ista računica odredila bi visinu stupova na oko 4,20 - 4,30 m, ali držimo da ju treba spustiti za barem jedan metar. Dubina bloka zasigurno je i jedan od pokazatelja nekadašnje duljine trabeacije i njezine izvedbe. Trabeacija je mogla biti sačinjena od jednog, dva ili najviše tri takva monolita. Iako su i na tome utemeljeni proračuni krajnje upitne vrijednosti, napravit ćemo jedan takav pokušaj.

Monolit gotovo iste funkcije (visine $0,59 \mathrm{~m}$, duljine $1,33 \mathrm{~m}$ i dubine $0,40 \mathrm{~m}$ ) otkriven 1937. godine u Puli nedavno je atribuiran grobnici tipa višekatne edikule. Zona arhitrava podijeljena mu je na tri fascije, dok friz ispunjava motiv oružja. ${ }^{79} \mathrm{G}$. Fischer $s$ pravom ga je pripisao trabeaciji grobnice i rekonstruirao iznad središnje interkolumne tetrastilnog pročelja. Time je prihvatio pretpostavku da su postojala još dva takva monolita ukupne duljine oko $4 \mathrm{~m} .{ }^{80}$ Duljina trabeacije u odnosu na dubinu tako bi bila u omjeru $10: 1$. Primijenimo li taj parametar na blok s natpisom Larcija, njegova ukupna duljina mogla bi iznositi oko 3,20 m, što i jest maksimalna procjena duljine. Upada u oči da su i kod pulskog i kod ninskog elementa monoliti izvedeni u visini od oko 2 rimske stope. To za rekonstrukciju sigurno nije nevažno, ali njihova dubina bez sumnje ukazuje na različitu duljinu koja ipak nije bila prevelika. Fischerovoj se rekonstrukciji može zamjeriti jedino to da je pulski blok mogao pripadati i bočnoj trabeaciji, no kako piramidalno krunište istog ansambla ukazuje na objekt četvrtaste osnove, to ne mijenja puno na stvari.

Dovevši u omjer širinu kapitela od oko 0,50 $\mathrm{m}$ i aproksimativnu duljinu bloka $\mathrm{s}$ natpisom od oko 3,20 m ili nešto manje, najizglednija je pretpostavka da je

77 O elevaciji zadarskog kapitolijskog hrama s osloncem na Vitruvija: Mate SuIć, Antički grad na istočnom Jadranu, Zagreb, 2003., Drugo dopunjeno izdanje, 293 i d., Sl. 143.

78 Usporedi Dražen MARŠIĆ, Ruža SE KSO, Korniž ranocarske građevine iz Nina, Vjesnik za arheologiju i povijest dalmatinsku, 105, Split, 2012., 28, Tab. 1, gdje se usporedno donose gabariti pojedinih arhitektonskih elemenata kapitolijskog hrama u Zadru i istovrsni elementi drugih dobro proučenih sakralnih zdanja na istočnom Jadranu.

79 Günther FisCher, Das römische Pola. Eine archäologische Stadtgeschichte, München, 1996., 133 i d., br. 2, T. 37b.

80 G. FisCher, Das römische Pola. Eine archäologische Stadtgeschichte, 134, Sl. 31. 
grobnica Larcija izgrađena u obliku edikule (pseudo-hrama), s dva stupa na pročelju (distilni prostil). Takvo tlocrtno rješenje najbolje odgovara otvoru koji bi preostao. ${ }^{81}$ No nije nemoguće da je pročelje imalo četiri stupa u nizu (manji tetrastilni prostil), što je daleko najčešće rješenje kod grobnica tipa edikule. ${ }^{82}$ To je pitanje dakako povezano s točnom duljinom natpisnog bloka koju u ovom trenutku ne znamo. Kolika je mogla biti duljina bočne trabeacije? Najčešća je praksa da je neznatno reducirana u odnosu na onu s pročelja. No nekada ju duljinom i ponavlja, dajući grobnici gotovo uvijek kvadratnu ili pravokutnu osnovu, pa takvu zamišljamo i ovdje. ${ }^{83}$ Polupalmete posve sigurno nisu bile jedini dekor bočnih strana, već ih treba vidjeti kao završetke duljih biljnih (akantovih?) povijuša. Prihvati li se rekonstrukcija u obliku distila, ispred anta je eventualno mogao biti još samo po jedan stup (ukupno na bokovima jedna interkolumna), a u slučaju tetrastila eventualno jedan više (ukupno dvije interkolumne). Međutim, dva ili četiri stupa u nizu na pročelju mogli su biti i jedini u predvorju.

Grobnica je sigurno imala prostor rezerviran za pokapanje. Kod edikula se on obično rješavao grobnom komorom unutar visokog kvadarskog podija. Podij se u sličnoj izvedbi pojavljuje kod različitih tipova građevina, npr. visokih pilastara, oltara i baldahina. No protiv mogućnosti postojanja takvog elementa u okviru grobnice Larcija upućuje pojava natpisa na elementu trabeacije, koji bi se tada nalazio razmjerno visoko. Zbog istih razloga isključujemo mogućnost da je cijela konstrukcija stajala kao baldahin neke infraponirane strukture. Na višekatnim edikulama $s$ visokim podijem natpis se naime obično nalazi na pročelju podija, makar u zasebnom polju pri vrhu, ali svakako ispod zone stupova. ${ }^{84}$ Trabeacija je kod njih tako podijeljena na arhitrav i friz i drukčije je dekoracije friza $s$ akantovim prepletom, vojnim znamenjem ili nekim drugim motivom. Iako

81 Jedna pod poznatijih edikula u tom tlocrtu je ona Aula Murcija Obulaka iz Sarsine u Italiji koja stoji na podiju osrednje visine. O njoj pregledno: Jacopo OrTALli, La via dei sepolcri di Sarsina. Aspetti funzionali, formali e sociali, Römische Gräberstraßen. Selbstdarstellung - Status - Standard, Kolloquium in München vom 28. bis 30. Oktober 1985 (ur. H. von Hesberg, P. Zanker), München, 1987., 167, Sl. 46, T. 23b, 24a, c.

82 Osim prethodno spomenute, tzv. "grobnice oružja“ iz Pule, od koje su, istina, ostali skromni, ali strukturalno odredivi fragmenti (vidi bilj. 80), neki primjeri takvih građevina su npr. Rufova edikula u Sarsini, vidi: J. Ortalli, La via dei sepolcri di Sarsina. Aspetti funzionali, formali e sociali, 167 i d., Sl. 48, T. 23c, 24b; Bibulova edikula u Rimu i edikula Poblicija u Kelnu, vidi: H. von Hesber G, Römische Grabbauten, 124, Sl. 71, 141 i d., Sl. 85.

83 Za takvu strukturu jedne distilne prostilne edikule v. shemu kod G. Kremer, Antike Grabbauten in Noricum. Katalog und Auswertung von Werkstücken als Beitrag zur Rekonstruktion und Typologie, 322 i d., Sl. 155 desno (sa zabatom, tj. krovnim strehama). Četvrtasti tloris imaju npr. sve grobnice navedene u bilješkama $80-82$.

84 Kod svih grobnica u bilješkama $81-82$ natpis je ili potvrđen na podiju ili nije prisutan u sklopu trabeacije. 
ima pokušaja da se neke grobnice $s$ natpisom na epistilu rekonstruiraju kao distilne edikule na visokom podiju, prema takvim smo prijedlozima za sada rezervirani. ${ }^{85}$ Iako nije a priori nemoguće da je i grobnica Larcija imala visoki podium, prije je mogla imati podrumski (ukopani) dio u funkciji cele. Također je mogla stajati i na pročelju grobnog areala namijenjenog ukapanju, kao što je npr. slučaj s brojnim monumentalnim spomenicima na jednom od najbolje poznatih isječaka Via Appia u Rimu ili na cesti ispred Porta Romana u Ostiji. ${ }^{86}$ U prvom dijelu rada nisu slučajno donijeti podatci o veličini grobnih areala u Enoni; oni pokazuju da je bilo areala/parcela širine 10 stopa ili oko $3 \mathrm{~m}$. Istina jest da arhitrav, friz is njima združene elemente vijenca za sada ne poznajemo kao elemente pročelja grobnih areala na istočnom Jadranu. No što je uopće poznato o izgledu njihova gornjeg dijela i prisutnim instalacijama, čak i u jednoj razmjerno dobro istraženoj Saloni? Tako se do nedavno držalo da su grobni areali zapadne salonitanske nekropole imali niske ograde na pročelju, tj. otvorene pogledu s ceste. No otkrića vrata s dovratnicima i gabariti zatečenih zidova u istraživanjima 1986./1987. godine upozorila su da je barem dio (najstarijih) areala imao zidove iznad ljudske visine. ${ }^{87}$ I primjeri iz grada Rima pokazuju da su pročelja grobnih areala u doba kasne republike i ranog carstva, obično direktno naslonjena na cestu, strukturom, dubinom i skulpturalnim detaljima veoma često imitirala pravu arhitekturu (neka su čak imala i zabate). No od nje su se razlikovala po tome što nisu bila natkrovljena, tj. što su takva zdanja funkcionirala kao otvorena dvorišta. ${ }^{88}$ Ipak, ona u pravilu nisu imala stupove u pročelju, već izgled fasade kuće ili oltara, iako su služila kao neka vrsta predvorja u stražnji dio areala.

85 Usporedi G. Kremer, Antike Grabbauten in Noricum. Katalog und Auswertung von Werkstücken als Beitrag zur Rekonstruktion und Typologie, 99 i d., Kat. I 32, S1. 64 - 66, Tab. X (Faschendorf u Noriku; grobnica se rekonstruira kao tetrastilna edikula).

86 H. von Hesberg, Planung und Ausgestaltung der Nekropolen Roms im 2. Jh. n. Chr., Römische Gräberstraßen, 51 i d., T. 3a-b (Via Appia); Dietrich Boschung, Die republikanischen und frühkaiserzeitlichen Nekropolen vor den Toren Ostias, Römische Gräberstraßen. Selbstdarstellung - Status - Standard, Kolloquium in München vom 28. bis 30. Oktober 1985 (ur. H. von Hesberg, P. Zanker), München, 1987., 113 i d., S1. 15 i 16 (Porta Romana); Sličan koncept prisutan je i na drugim nekropolama, npr. onima spomenutima kasnije u bilješci 88 .

87 Važne konstatacije: Željko Miletić, Murazzo zapadne salonitanske nekropole, Radovi Filozofskog fakulteta u Zadru, 28(15), Zadar 1989., 62 i d., Sl. 3 (tzv. vrata 1), 66 (rasprava o visini i izgledu). U nedavnom razgovoru kolega Miletić ponovno je izrazio čvrstu uvjerenost da su neki areali imali visinu prave arhitekture. O dimenzijama areala, nazivlju koje se pojavljuje na epitafima i vrstama spomenika usporedi i N. CAмBi, Salona i njene nekropole, 1986., 65 i d. (= Salona und seine Nekropolen, 1987., 253 i d.).

88 Usporedi H. von Hesberg, Planung und Ausgestaltung der Nekropolen Roms im 2. Jh. n. Chr., Römische Gräberstraßen, 46 i d., Sl. 5 (Via Celimontana), 48, Sl. 7 (Via Salaria). Pregledno: H. von Hesberg, Römische Grabbauten, 57 - 60 i d., S1. 17 i d. 


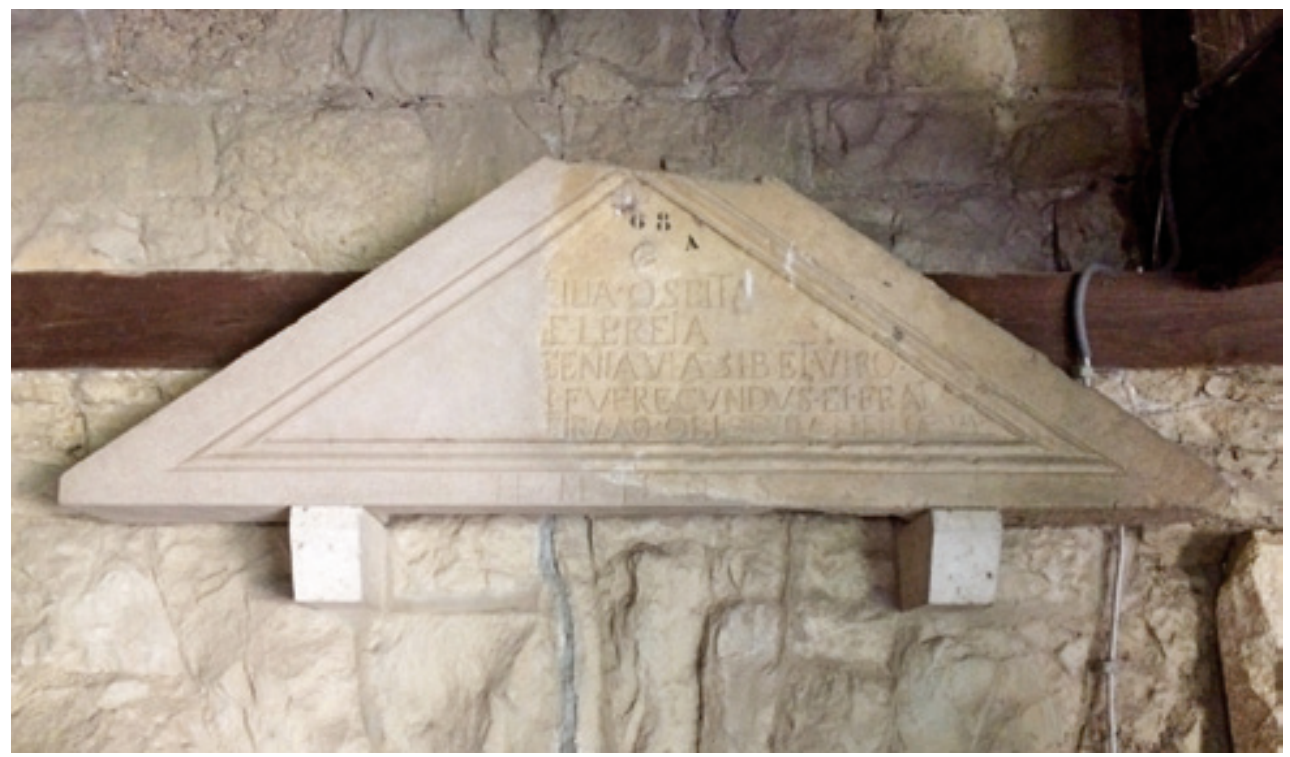

SLIKA 17. Zabat distilne edikule iz Salone (foto: D. Maršić)

Edikula Larcija očito je bila samostojeća građevina, ali ne možemo isključiti mogućnost da je stajala i u nekom složenijem arhitektonskom kontekstu, npr. da se na nju naslanjao perimetralni zid grobnog prostora.

Grobne edikule distilnog i tetrastilnog pročelja sigurno su bile poznate u priobalju rimske provincije Dalmacije. O tome posredno svjedoče brojni spomenici među kojima najvažniji potječe očekivano iz Salone. Riječ je o desnoj polovici manjeg zabata s rozetom pri vrhu i natpisom u ostatku polja (CIL 3, 8902), na čijoj se donjoj plohi, blizu desnog ugla, sačuvao duboki utor za stup. ${ }^{89}$ Zabat je danas rekonstruiran i izložen u Arheološkom muzeju u Splitu i nema nikakve sumnje da pripada distilnom pročelju grobnice široke oko $1,2 \mathrm{~m}$ (S1. 17).

Druga dva zanimljiva nalaza potječu iz kolonije Jader. Na gradskoj nekropoli Relja otkrivene su u sekundarnom kontekstu (kao podnica groba) dvije stropne ploče koje se ne mogu međusobno spojiti, što znači da nedostaje još barem jedna..$^{90} \mathrm{Na}$ jednoj su ploči sačuvani peterostruki profili na tri strane, potom donje ravne plohe za sidrenje na konstrukciju formiranu od zidova ili

89 Koliko nam je poznato, spomenik (osim natpisa) nije objavljen ni detaljnije analiziran.

90 Iscrpna analiza ploča: Nenad CAмBI, Stropni reljef iz Aserije, Asseria, 2, Zadar, 2004., 32 i d., Sl. 7 - 9. Autor grobnicu naziva „Vrstom edikule“ i pretpostavlja da je mogla imati 3 ili 4 stropne ploče nad komorom. Datira ju u prvu polovicu 2. st. 
okomitih ploča i vjerojatno polovica središnjeg dekora u obliku romboidnog polja upisanog u kvadratno polje $s$ ugaonim rozetama (u središtu romba je krilata ženska figura - nyx?). Na drugoj su ploči prisutni isti profili, ali čini se i utori za dva stupa. Morfologija i instalacije ploča tako generiraju prilično pouzdan zaključak da je riječ o stropnim pločama komore u cijeloj njezinoj širini, ali problematične duljine, najvjerojatnije tipa manje distilne edikule.

Jednako je zanimljiva pojava piramidalnog kruništa sjevernoitalskog tipa. Ono je moglo pripadati većoj nadgrobnoj ari ili još prije manjoj edikuli s podijem, ali svakako grobnici četvrtaste osnove. ${ }^{91}$ Objavljen je i analiziran samo njegov vršni dio, ukrašen na sve četiri strane s tri uzorka akantova prepleta (jasno se razlikuju prednja, stražnja i bočne stranice). No nedavno je otkriven i nastavak te su zajedno izloženi na travnjaku zadarskog foruma (Sl. 18). Jasno se vidi da mu i dalje nedostaje završni donji dio, koji se konveksno svijao i širio prema uglovima. To navodi na pomisao da mu je izvorna visina mogla dosezati barem dvostruku visinu danas sačuvanog korpusa (dulj. 0,6 x vis. $0,94 \mathrm{~m}$ ). ${ }^{92}$ Tako projicirana visina prije odgovara jednoj većoj grobnoj edikuli negoli ari. Dva jadertinska spomenika jasno svjedoče da je u Jaderu bila prisutna moda uporabe edikula i da su neki spomenici imali pokrove ili kruništa sjevernoitalskog tipa. Odatle i opravdana pretpostavka o prisutnosti edikula nalik onima u Sarsini ili Puli, s distilnim ili tetrastilnim pročeljem, u gradu i okolici. ${ }^{93}$ Time smo se približili važnom pitanju, kakvoga je izgleda moglo biti nadgrađe grobnice Larcija? Ono je sigurno bilo riješeno na jedan od dva načina: $s$ piramidalnim pokrovom ili u obliku krova na dvije vode. Prva bi varijanta bolje odgovarala građevini na visokom kvadarskom podiju, a druga nižoj građevini na podiju hramskog tipa.

Ugradbeni reljef $s$ fotografije dr. L. Jelića (Sl. 13) i onaj s lokaliteta Dvorine (S1. 16) svojom poprečnom koncepcijom i ravnom prednjicom također iskazuju pripadnost četvrtastim grobnim strukturama. U Dalmaciji nisu dokumentirani in situ sačuvani primjerci takvih reljefa. O njihovu izvornom kontekstu doznajemo tek preko primjera iz grada Rima i okolice, o čemu je već bilo riječi. Oni pokazuju da su reljefi uvijek stajali na fasadama grobnih zdanja. Nekada su se nalazili u visini svojevrsnih prozora obzidanih grobnih areala bez krova, ili spomenika interpoliranih na pročelja ranije izgrađenih areala, koji su zbog pojave vrata,

91 D. MARŠIć, Piramidalna kruništa iz Aserije, Asseria, 4, Zadar, 2006., 111 i d., sl. 10 (datacija u prvu polovinu 2. st.).

92 D. MARšić, Piramidalna kruništa iz Aserije, 115, gdje se konstatira da bi takvim gabaritima krunište bilo usporedivo nekima iz Sarsine i pulskome s prikazom oružja.

93 Usporedi bilješke 80 - 82: G. FISCHER, Das römische Pola. Eine archäologische Stadtgeschichte; J. OrTALLI, La via dei sepolcri di Sarsina. Aspetti funzionali, formali e sociali. 


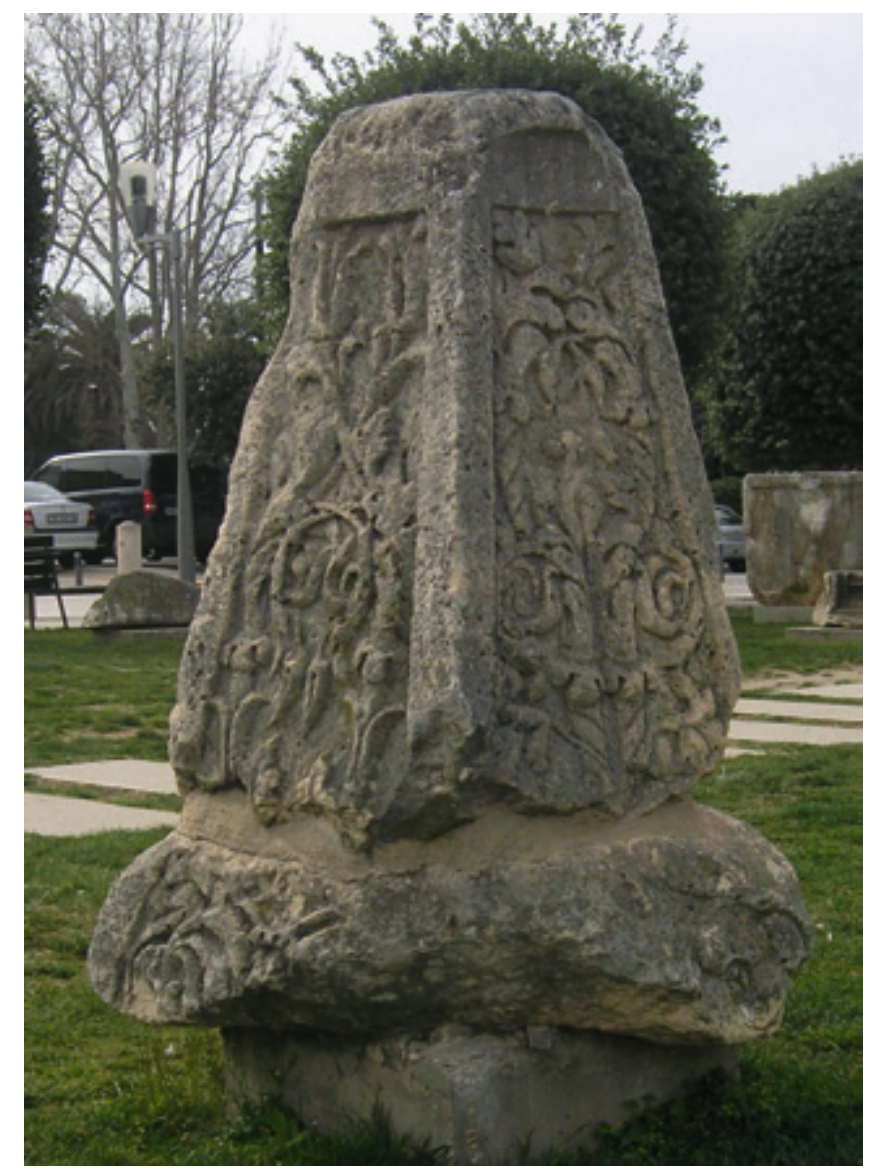

SLIKA 18. Piramidalno krunište monumentalne grobnice iz Zadra (foto: D. Maršić)

vijenca, zabata i dr. elemenata ipak stvarali iluziju pravih građevina. ${ }^{94}$ Nekada su pak stajali u visini vidnog polja na manjim, čvrsto zidanim grobnicama, od kojih su neke i sačuvane ili rekonstruirane s većom sigurnošću. ${ }^{95}$ Neki drugi kontekst teško da može doći u obzir, npr. unutar kolumbarija, jer su naši primjerci višefiguralni i masivne poprečne koncepcije, što ne odgovara gradskorimskim primjercima reljefa koji dolaze iz takvog konteksta.

94 O karakteristikama reljefa i portreta pregledno Paul ZANKER, Grabreliefs romischer Freigelassener, Jahrbuch des Deutschen Archäologischen Instituts, 90, Berlin, 271 i d., Sl. 4; Za arhitekturu usporedi Valentin Kockel, Porträtreliefs stadtrömischer Grabbauten, Mainz am Rhein, 1993., 7, 83 i d., Kat. A 1-2, T. 1a; Vidi i ovdje bilješka 88 (Via Celimontana).

95 Npr. P. Zanker, Grabreliefs romischer Freigelassener, 273 - 274, Sl. 5 (Via Appia); V. Kockel, Porträtreliefs stadtrömischer Grabbauten, 1993., 8, T. 2a (isto). 


\section{ZAKLJUČAK}

Paradoksalno je da nekropole antičke Enone usprkos slabije dokumentiranosti istraženih dijelova donose više spoznaja o monumentalnoj grobnoj arhitekturi i pripadajućoj skulpturi negoli susjedne u Jaderu i Argiruntu. U Argiruntu su poznati samo zidani areali visine „do pola metra“ i zidova širine $0,50-0,60$ $\mathrm{m}$ sačuvani $\mathrm{s}$ obje strane ceste. ${ }^{96}$ No morfologija jednog natpisa mogla bi ići u prilog razmišljanju da je i tu, kao i u Saloni, bilo visokih areala ili monumentalnih nadzemnih grobnica. ${ }^{97} \mathrm{U}$ Jaderu su pak najbolje dokumentirani zidani areali otkriveni predaleko od gradskih zidina, dok o onima bliže gradu znamo malo ili gotovo ništa. ${ }^{98} \mathrm{Da}$ su glavnu cestu iz grada južnije od uvale Jazine i dalje prema istoku mjestimice pratila monumentalna grobna zdanja, jasno pokazuju ostatci masivne temeljne supstrukcije okružene grobovima i flankirane $s$ dva ogradna zida, otkrivene u istraživanjima 2006. godine. ${ }^{99}$

Nekropole i grobne areale Enone ne treba zamišljati samo kao niske ograđene zone, nego i s visokim i kompaktno zidanim građevinama, najvećim dijelom podignutim u 1. st. prije i poslije Kr. Do nedavno su na njih upućivali rijetki primjerci reljefa s instalacijama netipičnim za stele. Spomenuti reljefi nisu nikada ugrađivani pri zemlji, nego barem u visini očiju ili naviše, a iznad njih su u pravilu slijedili i drugi arhitektonski detalji (vijenac i dr.). ${ }^{100}$ Sada pak raspolažemo i prvim konkretnijim ostatcima temeljnih i konstruktivnih dijelova arhitekture pojedinih grobnica, i to različite morfologije.

Čak dva nalaza obrađena u ovom radu - blok s natpisom Larcija (Sl. 10) i reljef $s$ fotografije B. Ilakovca (Sl. 16) - potječu s položaja Dvorine na južnom, rubnom

96 M. Abramić, A. Colnago, Untersuchungen in Norddalmatien, 1909., 52, sl. 19. Pregledno: N. CAмвi, Salona i njene nekropole, 1986., 90 i d., sl. 14 (= Salona und seine Nekropolen, 1987., 273 i d., sl. 88).

97 M. Abramić, A. Colnago, Untersuchungen in Norddalmatien, 1909., 51, sa slikom spomenika. Natpis se danas nalazi u Arheološkom muzeju Zadar i na gornjoj plohi ima kanal za klamfu (vratni nadvoj?).

98 Branka Nedved, Zaštitno istraživanje rimskih grobova u Zadru, Diadora, 9, Zadar, 1980., 341 - 345; Pregledno: N. CAmbi, Salona i njene nekropole, 1986., 92 i d., sl. 16 (= Salona und seine Nekropolen, 1987., 276, sl. 90); Neki grobni areali na tadašnjem početku Benkovačke ceste (danas ulica I. Zadranina) bili su manji i odvojeni od ceste manjim pristupom - nogostupom, a drugi direktno naslonjeni na cestu i nešto veće identične dubine, što ipak ukazuje na pomno planiranje.

99 Šime PErović, Ivo FAdić, Zaštitno arheološko istraživanje dijela antičke nekropole Zadra u Zrinsko-Frankopanskoj ulici, Diadora, 23, Zadar, 2009., 49 i d., sl. 3, 8 i 11, gdje se naziva „konstrukcijom 2“i pripisuje većoj edikuli ili mauzoleju.

100 Važna zapažanja o prisutnosti tzv. ugradbenih reljefa u Enoni i susjednoj Arbi, u to vrijeme još gotovo nepoznate vrste spomenika: N. CAмBI, Salona i njene nekropole, 1986., 94, bilj. 140 (= Salona und seine Nekropolen, 1987., 277, bilj. 167). 
dijelu ninskog otoka. Oba su pronađena u sekundarnom kontekstu, uzidana kao spoliji u konstrukciju kasnoantičkog bedema. Mjesto s kojega su ti elementi uzeti može biti samo obližnja, preko mosta smještena nekropola, za koju smo rekli da se može okarakterizirati kao ,južna nekropola“. Tako se pokazuje točnim zaključak dr. L. Jelića da su se na njoj nalazile osobito monumentalne grobnice.

Muški likovi s reljefa analiziranih u ovom radu (Sl. 13 i 16) neupitno su prikazani u togama, zbog čega ih se mora prepoznati kao osobe s građanskim statusom. Zanimljivo je da su i na druga dva sigurno prepoznata ugradbena reljefa iz Nina muškarci prikazani u togama. To govori o znatnoj ekonomskoj snazi i prosperitetu najvažnijeg među gradskim ordima. Prikazi togata na reljefima Enone mogu se nadalje podijeliti u dvije jasno izdvojene kronološke grupe, obje iz 1. st. po Kr. Na prvoj nose togu ranocarskog tipa s izvučenim umbom „U“ oblika, a na drugoj togu s visoko nategnutim i naboranim umbom. To pokazuje u kojoj su mjeri stanovnici grada pratili suvremene modne trendove i donekle oslikava onodobni kulturni milje.

Osnovna je ideja rimskog društva, kao i mnogih prije njega, bila pretočiti ideju o grobu kao mjestu vječnog prebivališta (domus aeterna) i buduće kultne aktivnosti, odgovarajućim arhitektonskim i likovnim jezikom, što je trebalo rezultirati stvaranjem luksuznog i ugodnog okruženja (locus amoenus). Najvažniji elementi tog jezika bili su u ranije carsko doba visoki grobni areali i samostojeće građevine različitih vrsta, tj. pravi mauzoleji. Aenona je očito bila iznimno prosperitetna zajednica, što posredno doznajemo iz različitih izvora. Ne treba sumnjati da se taj prosperitet reflektirao i na području nadgrobne arhitekture i umjetnosti, gdje je uvijek vladalo svojevrsno natjecanje između pripadnika istih i različitih društvenih grupa. Nama su danas nažalost poznate samo rijetke kockice toga bogatog mozaika, a najbolje prilike za istraživanja već su davno propuštene krajem 19. i početkom 20. st. 


\section{Martina DUBOLNIĆ GLAVAN \\ Dražen MARŠIĆ}

\section{MONUMENTAL TOMBSTONE ARCHITECTURE AND RELIEF SCULPTURE OF ROMAN AENONA}

\section{SUMMARY}

The acceptance of Roman cultural heritage in Liburnia is reflected, among other things, in the funerary practice of erecting very lavish and monumental constructions as eternal resting places for members of the social elite and their families. Evidence of their existence is rarely preserved, and due to their fragmentation and non- epigraphic character, they have often remained out of the focus of scientific research. This paper, for the first time, integrally deals with the essential remains, structural elements and reliefs with portraits of the deceased, once built into the facades of burial constructions (so-called embedded reliefs) as evidence of the existence of different types of monumental tombstone architecture and sculpture in the Roman municipality of Aenona (Nin).

The first section of the paper synthesizes the knowledge about the necropoles of Roman Aenona with particular emphasis on the raster of the cemeteries (Fig. 1 ), types of monuments, information on the size of the tomb areas and the most monumental buildings, until now known only through embedded portrait reliefs built into their facades (Figs. 2 - 4).

The second section of the paper introduces new insights into the topic of monumental tombstone architecture and the associated relief sculptures of Roman Aenona. Firstly, it discloses and analyses part of the photographic documentation from the Roman mausoleum survey at the site of Kulin in Vrsi in 1972 (Figs. 5 - 8). The building is compared to the mausoleum in Muline on the island of Ugljan, typologically defined as a "tomb of the house type" and dates roughly to the 3rd - 4th century. Then it carries a thorough analysis and interpretation of the monolithic fragment of entablature with the inscription area on the front and a frieze and architrave on the lateral side, with associated installations on the upper and lower surfaces (Figs. 9-12). It is found that it must have stood on the pillars and belonged to the "temple tomb" of the Lartius family of the type di-style or tetra-style (two or four-column temple) prostilos aedicula, probably built in the 1 st century, but certainly not later than the middle of the 2nd century.

The last section of the paper deals with two embedded reliefs, once built into the facades of monumental burial structures. We learn about the appearance of 
the former from a photograph found in the Archive of Dr L. Jelić, taken at the beginning of the 20th century (Fig. 13). The relief then depicted three togati and a shoulder of the fourth character, with only the central figure of a young man remaining to date (Figs. 14-15). The analysis of clothing and stylistic details date back to the Flavian era. The latter is also known only from a photograph published in 1970 in the work of B. Ilakovac (Fig. 16). It portrayed a togatus boy with a bulla around his neck wearing a toga praetexta, so it is assumed that the deceased was shown initially with one or both parents. The relief dates back to the earlier Julian-Claudian period, as the two already known examples of the same type of monument (Figs. 2 - 4).

For the study of monumental tomb structures, their funerary context is also essential. The paper especially emphasizes the size of burial areals and types of tombstones and mainly summarizes the results of recent studies of the city necropoles raster (Fig. 1). Analogies for reconstructing the appearance of these buildings, as well as their function and location within the city necropoles, can be found in the area of the province of Dalmatia in Salona (Fig. 17), Jader (Fig. 18) and more often at the necropoles of the city of Rome.

The backbone of the research carried out for this work was the museum material, and documentation kept in the Zadar Archaeological Museum and the Museum of Antiquities in Nin. The results of the typological-comparative method applied in the analysis of the monuments were supplemented by the data collected through research of archival material. The raster study of urban necropoles involved landscape archaeology as well. Also, the results of the archaeological field survey and remote sensing carried out in the Nin urban area were implemented in the discussion.

Keywords: Aenona, Roman necropoles, burial grounds, mausoleums, embedded reliefs, portraits. 